\title{
Minting in Vandal North Africa: coins of the Vandal period in the Coin Cabinet of Vienna's Kunsthistorisches Museum
}

\author{
Guido M. B ERNDT \\ Roland S Teinacher
}

This paper offers a re-examination of some problems regarding the coinage of Vandal North Africa. The coinage of this barbarian successor state is one of the first non-imperial coinages in the Mediterranean world of the fifth and sixth centuries. Based on the fine collection in the Coin Cabinet of Vienna's Kunsthistorisches Museum, this article questions the chronology of the various issues and monetary relations between the denominations under the Vandal kings, especially after the reign of Gunthamund (48496). The Vandals needed and created a solid financial system. In terms of political, administrative and economic structures they tried to integrate their realm into the changing world of late antiquity and the early Middle Ages.

\section{Introduction}

The Münzkabinett of the Kunsthistorische Museum in Vienna holds a collection of coins of the Vandal period (429-534), including coins

* We would like to express our thanks to Michael Alram of the Coin Cabinet in the Kunsthistorisches Museum of Vienna for giving us the opportunity to examine the original coins. We are also grateful to Wolfgang Hahn and Michael Metlich of the Institut für Numismatik at the University of Vienna, Nikolaus Schindel of the Numismatische Kommission at the Österreichische Akademie der Wissenschaften, Frank M. Clover (Madison, WI) and Sebastian Steinbach (Osnabrück), for their invaluable advice. Furthermore, we thank Walter Pohl for offering us hospitality in Vienna and allowing us to use the facilities of the Institut für Mittelalterforschung der Österreichischen Akademie der Wissenschaften. First results have already been published by the authors as 'Die Münzprägung im vandalenzeitlichen Nordafrika: Ein Sonderweg?', in R. Rollinger and B. Truschnegg (eds), Altertum und Mittelmeerraum: Die antike Welt diesseits und jenseits der Levante, FS Peter W. Haider, Oriens et Occidens 12 (Stuttgart, 2006), pp. 599-622. Dr Julia Hillner, Dr Paul Fouracre and Dr Susan Vincent deserve many thanks for their meticulous and dedicated work at the different stages of translation.

Early Medieval Europe 2008 I6 (3) 252-298

(C) 2008 The Authors. Journal Compilation (C) 2008 Blackwell Publishing Ltd, 9600 Garsington Road, Oxford OX 4 2DQ, UK and 350 Main Street, Malden, MA 02148, USA 
minted by the Vandal kings. This collection consists of thirteen silver coins, seventy-five bronze and copper coins, and ten incised Roman imperial large and middling bronze coins. It used to be part of the former Austrian imperial numismatic collection and was assembled over the course of three centuries. The present study seeks to establish, on the basis of the available numismatic evidence and past scholarship, the value of the coins of Vandal North Africa as a historical source. The appendix of this article contains a catalogue of the coins in the numismatic collection in Vienna connected to the Vandal kings.

The coinage of the barbarian regna in the Roman empire is particularly useful in problematizing the barbarian warrior elites' desire for integration into the changing Mediterranean world of late antiquity and the early Middle Ages. Traditional historic and numismatic scholarship used to consider the coinage of the gentes of the migration period in an isolated context. They were often seen as individual expressions of politically and economically independent states. This approach anachronistically anticipated later medieval legal structures. We can note the basic tendency of these assumptions clearly even in more recent publications, to an extent that makes necessary a reappraisal of Vandal coinage in its historical context. We will attempt this in a way that will consider the complexity of the last decade's active and fruitful international research. ${ }^{2}$

After they had remained on the Iberian peninsula for twenty years, the Vandals ceded to the pressure of the Goths who acted as imperial agents. In 429 Geiseric led them and a group of Alans over the Mediterranean Sea to North Africa. As they did not meet with any serious resistance, the Vandals moved east, where they besieged and seized Hippo Regius, St Augustine's episcopal see, in 43I. The important and wealthy metropolis of Carthage, the centre of North Africa, remained under Roman rule. Africa was one of the most prosperous regions in the Roman empire. In 439, however, the Vandals conquered Carthage after a surprise attack, and now established a regnum in the wealthy provinces of Byzacena and Proconsularis - roughly modern-day Tunisia - that was comparable to the later kingdom of the Ostrogoths in Italy. The imperial government in Ravenna accepted this situation in 442

In the following notes, references to coins in the catalogue are in bold.

Especially the European Science Foundation's multi-volume project, Transformation of the Roman World. Also W. Goffart, Barbarian Tides: The Migration Age and the Later Roman Empire (Philadelphia, 2006); W. Pohl, Die Völkerwanderung. Eroberung und Integration (Stuttgart, 2002); H. Wolfram, The Roman Empire and its Germanic Peoples (Berkeley, 1997); the two volumes L'Afrique vandale et Byzantine, Antiquité tardive IO (2002) and II (2003); G.M. Berndt and R. Steinacher (eds), Das Reich der Vandalen und seine (Vor-)Geschichten, Forschungen zur Geschichte des Mittelalters I3 (Vienna, 2008) forthcoming. 
with a treaty. In the following years the Vandals managed to take control of the western Mediterranean, where Sardinia, Corsica, Sicily and the Balearic Islands at least temporarily came under Vandal control. They also repeatedly looted the coasts of Greece and southern Italy, and the nineteenth-century German historian Felix Dahn spoke of Geiseric as a fierce 'king of the sea' (Meerkönig). ${ }^{3}$ The relationships with the eastern part of the empire nevertheless became more stable in 476 , with a treaty that promised 'eternal peace'. Only one year later Geiseric died after a reign of nearly fifty years.

The exact organization of the Vandal regnum is an object of scholarly debate. ${ }^{4}$ The most serious danger for the Vandals, after the treaty with Byzantium, arose from the Berbers. The Berbers had manifold relationships with both Vandals and Romans. ${ }^{5}$ They provided troops against the Romans during Geiseric's landing, and the Vandals subsequently continued to use them as sailors and soldiers.

Huneric (477-84), the second rex Vandalorum et Alanorum, was succeeded by his two nephews Gunthamund (484-96) and Thrasamund (496-523). In 523 Geiseric's grandson Hilderic became king. However, in 530 a group of Vandal aristocrats proclaimed Geiseric's great-grandson, Gelimer, king. Hilderic and other family members were imprisoned. This putsch provided an opportunity for the emperor Justinian to intervene on the basis of the treaty of 476. In 533 the Byzantine army, led by Belisarius, conquered the Vandal kingdom. Gelimer, the last Vandal king, was led a prisoner to Justinian in Constantinople. ${ }^{6}$ As he was a relative of the emperor - in the fifth century, in an attempt to safeguard peace, Huneric had married the daughter of Valentinian III, thus establishing a family relationship between the Vandal royal family

F. Dahn, Die Könige der Germanen. Die Zeit vor der Wanderung (Munich, I86I).

For the administrative structures see recently G. Maier, Amtsträger und Herrscher in der Romania-Gothica. Vergleichende Unteruchungen zu den Institutionender ostgermanischen Völkerwanderungsreiche, Historia Einzelschriften I8I (Stuttgart, 2005).

Y. Moderan, Les maures et l'Afrique romaine. IVe - VIIe siècle, Bibliothèque des Écoles françaises d'Athènes et de Rome 314 (Rome, 2003); C. Courtois, Les Vandales et l'Afrique (Paris, 1955), pp. 325-59; H.J. Diesner, Das Vandalenreich. Aufstieg und Untergang (Stuttgart, Berlin, Cologne and Mainz, 1966), pp. I45-50.

6 Vandal history: G.M. Berndt, Konflikt und Anpassung: Studien zu Migration und Ethnogenese der Vandalen, Historische Studien 489 (Husum, 2007); H. Castritius, Die Vandalen. Etappen einer Spurensuche (Stuttgart, 2007); H. Castritius, 'Wandalen $\ \mathrm{I}$ ', in Reallexikon der Germanischen Altertumskunde 33, 2nd edn (Berlin and New York, 2006), pp. 168-209; A. Merrills, 'Introduction', in A. Merrills (ed.), Vandals, Romans and Berbers: New Perspectives on Late Antique North Africa (Aldershot, 2004), pp. 3-28; W. Pohl, 'The Vandals: Fragments of a Narrative', in Merrills (ed.), Vandals, Romans and Berbers, pp. 3I-47; Pohl, Die Völkerwanderung, pp. 73-85; Wolfram, The Roman Empire and its Germanic Peoples, pp. 159-82; H.J. Diesner, 'Vandalen', in Paulys Realencyclopädie der classischen Altertumswissenschaft [hereafter RE] Supplement X (1965), pp. 957-92; F. Miltner, 'Vandalen', in RE VIII A I (Stuttgart, 1955), pp. 298-335. 
and the Theodosian dynasty ${ }^{7}$ - he had the choice between exile with his family on a countryside estate to the north of the capital, or giving up Arianism and becoming a member of the senate. ${ }^{8}$

Historical analysis of Vandal North Africa from an economic point of view is rare. According to the influential work of the Belgian historian $\mathrm{H}$. Pirenne, the unity of the Mediterranean world was not destroyed during the migration period, but only with the advent of the Arabs. ${ }^{9}$ In a complex study the American scholar M. McCormick rejects Pirenne's thesis, and shows economic decline as an overall trend in the Roman world from the third century onwards. According to McCormick, the causes of this reduction in trade were general demographic decline, reduction in manufacture, such as metallurgy and ceramic production, and diseases, such as the plague. ${ }^{10}$ Yet, Mediterranean trade never ceased. Although McCormick does not particularly consider the Vandal evidence, he nonetheless provides an economic framework. VandalAlanic North Africa was not isolated, but was characterized by lively exchange with contemporary barbarian regna. This is a phenomenon we will come back to during our discussion of types of coinage. Considerable diplomatic contacts, as well as continuous activities in overseas trade, show that the Vandals by no means disrupted shipping routes. We know of five or six fifth-century shipwrecks opposite the Gallic coasts. The cargo of three of these ships consisted of tableware and amphorae from North Africa. This archaeological evidence indicates the integration of Vandal North Africa into the economic structures of the entire late antique Mediterranean world.

\section{The state of research: one hundred and fifty years of bewilderment}

The first scholarly publication on Vandal coinage was Julius Friedländer's short 1849 monograph Die Münzen der Vandalen." Since the midnineteenth century, numismatists have assigned coins to individual kings, beginning with Gunthamund (484-96). All royal silver and copper coins, as well as a large number of the anonymous bronze coins, have

G.M. Berndt, 'Die Heiratspolitik der hasdingischen Herrscher-Dynastie. Ein Beitrag zur Geschichte des nordafrikanischen Vandalenreiches', Mitteilungen des Vereins für Geschichte and der Universität Paderborn 15.2 (2002), pp. I45-54; J.P. Conant, 'Staying Roman: Vandals, Moors, and Byzantines in Late Antique North Africa, 400-700', Ph.D. thesis, Harvard University (2004), pp. 28-44.

8 Courtois, Les Vandales, p. 345; L. Schmidt, Geschichte der Vandalen (Leipzig, I9oI; Dresden, 1942), p. 178.

H. Pirenne, Mahomet et Charlemagne (Paris and Brussels, 1937).

ro M. McCormick, Origins of the European Economy: Communications and Commerce, AD 300-900 (Cambridge, 200I), p. 30

II J. Friedländer, Die Münzen der Vandalen (Leipzig, I849). 
been ascribed to his reign. ${ }^{\mathrm{I2}}$ From the beginning of academic discussion, scholars have remained extremely uncertain about coinage during the reigns of Geiseric (428-77) and Huneric (477-84).

The catalogue of the British Museum, dating to I9II, is still widely used, although it is largely outdated. ${ }^{13}$ Individual studies by AngloAmerican scholars in particular, have contributed to a more differentiated understanding. An example is the chapter on the Vandals in the early medieval volume of P. Grierson and M. Blackburn's Medieval European Coinage. ${ }^{14}$ M. Hendy's study of Byzantine numismatics contains a chapter on Vandal coinage, which has influenced many aspects of metrology. ${ }^{15}$ F.M. Clover has examined specific issues in a number of articles, for example his proposed dating of coins to Carthaginian city eras. ${ }^{16}$ The number of published Vandal coins has increased enormously thanks to the University of Michigan's extensive archaeological project in Carthage, and is easily accessible through the annual site reports. ${ }^{17}$ Representative of French research are the studies by C. Morrisson, ${ }^{18}$ R. Turcan ${ }^{19}$ and P. Salama. ${ }^{20}$ Morrisson's article 'Caratteristiche ed uso della moneta protovandalica e vandalica', published in 200I, summarizes

I2 C. Morrisson, 'Coin Finds in Vandal and Byzantine Carthage: A Provisional Assessment', in Excavations at Carthage: A Byzantine Cemetery at Carthage (Michigan 1988), pp. 423-36.

${ }_{13}$ W. Wroth (ed.), Catalogue of the Coins of the Vandals, Ostrogoths and Lombards and of the Empires of Thessalonica, Nicaea and Trebizond in the British Museum [hereafter BMC Vand] (London, I9II; repr. Chicago, 1966).

${ }^{14}$ P. Grierson and M. Blackburn, Medieval European Coinage: With a Catalogue of the Coins in the Fitzwilliam Museum, Cambridge I: The Early Middle Ages sth-Ioth Centuries [hereafter MEC] (Cambridge, 1986). For basic conclusions see also P. Grierson, 'The Tablettes Albertini and the Value of the Solidus in the Fifth and Sixth Centuries AD', Journal of Roman Studies 49 (1959), pp. 73-80.

Is M.F. Hendy, Studies in the Byzantine Monetary Economy c.300-I450 (Cambridge, 1985), pp. $478-90$.

16 F.M. Clover, 'Felix Karthago', Dumbarton Oaks Papers 40 (1986), pp. I-I6, also printed in F.M. Clover, The Late Roman West and the Vandals (Norfolk, I993), no. IX. F.M. Clover, 'Timekeeping and Dyarchy in Vandal Africa', in Antiquité tardive 11 (2003), pp. 45-63.

${ }_{17}$ T.V. Buttrey, 'The Coins - 1975', in J.H. Humphrey (ed.), Excavations at Carthage 1975. Conducted by the University of Michigan I (Tunis, 1976), pp. 157-97. T.V. Buttrey and B.R. Hitchner, 'The Coins - 1976', in J.H. Humphrey (ed.), Excavations at Carthage 1976. Conducted by the University of Michigan IV (Michigan, 1978), pp. 99-163. W.E. Metcalf and B.R. Hitchner, 'The Coins - 1977', in J.H. Humphrey (ed.), Excavations at Carthage 1977. Conducted by the University of Michigan V (New Delhi, 1980), pp. 185-270. W.E. Metcalf, 'The Coins - 1978', in J.H. Humphrey (ed.), Excavations at Carthage 1987. Conducted by the University of Michigan VII (Michigan, 1982), pp. 63-168. R. Reece, 'Coins', in H.R. Hurst (ed.), Excavations at Carthage. The British Mission II, I: The Circular Harbour, North Side (Oxford, 1994), pp. 249-56.

18 C. Morrisson, 'Les origins du monnayage vandale', Actes du sème Congrès International de Numismatique (Paris, 1976), pp. 459-72; C. Morrisson, 'La circulation de la monnaie d'or en Afrique à l'époque vandale. Bilan des trouvailles locales', in H. Huvelin, M. Christol and G. Gautier (eds), Mélanges de numismatiques. Offerts à Pierre Bastien (Wetteren, 1987), pp. 325-44.

19 R. Turcan, 'Trésors monétaires trouvés à Tipasa: La circulation du bronze en Afrique romain et vandale aux V et VI siècles', Archéologie-épigraphie 9 (I96I), pp. 207-57.

20 P. Salama, 'Les monnaies récoltées en 1974', in Il Castellum del Nador. Storia di una fattoria tra Tipasa Caesarea (Rome, I989), pp. 94-IIO. 
the state of research and presents an extensive bibliography.2 W. Hahn dedicates a chapter to Vandal coinage in his Moneta Imperii Byzantini, where he attempts a reconstruction of the Vandal coin system. ${ }^{22}$ His assignment of the bronze 42-, 2I- and 4-nummus pieces of Carthaginian origin to the reign of the last Vandal king, Gelimer (530-3/4), demonstrates the difficulties that affect our understanding of Vandal coinage before Gunthamund. These nummi, representing a figure that resembles a standing king holding a spear on the obverse, and a horse head on the reverse, had traditionally been ascribed to the first king, Geiseric. ${ }^{23}$ In $1998 \mathrm{~N}$. Schindel pleaded for an assignment of the so-called Domini Nostro series to the time of Geiseric. In this way, the first Vandal king would also finally get his coins. ${ }^{24}$

\section{The prosperity of the Vandal kingdom and the question of whether royal Vandal gold coins were ever minted}

The gold coins that Count John Francis William de Salis (I825-7I) and Warwick Wroth assigned to the Vandals are mostly of Visigothic or Burgundian origin. ${ }^{25}$ Wroth's conclusions are purely based on iconographic reflections. W.J. Tomasini showed that the gold coins under debate are closer stylistically to west European comparanda, and that the mint in Carthage did not serve as a model for mints in Gaul and Spain. ${ }^{26}$ The fact is that the solidi that were in circulation throughout the empire at this time constituted the apex of the monetary system in

${ }^{21}$ C. Morrisson, 'Caratteristiche ed uso della moneta protovandalica e vandalica', in P. Delogu (ed.), Le invasioni barbariche nel meridione dell'impero: Visigoti, Vandali, Ostrogoti (Rubbettino, 200I), pp. I5I-80.

22 W. Hahn, Moneta Imperii Byzantini I. Von Anastasius I. bis Justinianus I. (49I-565) einschließlich der ostgotischen und vandalischen Prägungen, Österreichische Akademie der Wissenschaften, Philosophisch-Historische Klasse, Denkschriften I09. Veröffentlichungen der Numismatischen Kommission I (Vienna, I973).

23 The 1997 monograph by H. Mostecky, Münzen zwischen Rom und Byzanz. Studien zur spätantiken Numismatik (Louvain-la-Neuve, 1997) presents an overview of the so-called 'proto-vandal' coins. The actual Vandal coinage is only considered in the course of an incomplete literature review, while Mostecky ignores almost completely the conclusions of recent historical research. The same author has published two substantial articles that discuss coin hoards in Sardinia and in Carthage: H. Mostecky, 'Ein spätantiker Münzschatz aus Sassari, Sardinien (2. Hälfte des fünften Jahrhunderts)', Rassegna di Studi del Civico Museo Archeologico di Milano 51/52 (I993), pp. I29-206; H. Mostecky, 'Ein spätrömischer Münzschatz aus Karthago', Numimatische Zeitschrift 102 (I994), pp. 5-165. But see the two-part review by N. Schindel, 'Die erste germanische Münze?', Money Trend 9 and 12 (1998), pp. 54-8 and 54-63 respectively, with its concise overview of the proto-vandal problem.

24 Schindel, 'Die erste germanische Münze?', p. 57.

${ }^{25}$ On Count de Salis see S. Bendall, 'A Neglected Nineteenth Century Numimatist', Spink Numismatic Circular 110/5 (2002), pp. 26I-3.

${ }_{26}$ Wroth, BMC Vand, p. XXI. For the complete discussion see W.J. Tomasini, 'The Barbaric tremissis in Spain and Southern France. Anastasius to Leovigild', American Numismatic Society: Numismatic Notes and Monographs 152 (1964), pp. 25-6 and Grierson, MEC, p. I9; Morrisson, 'Les origins', p. 462 and n. 6. 
the African provinces ruled by the Vandal kings. Trade benefited from use of a single currency. ${ }^{27}$ The Vandals respected the imperial right to mint gold coins; no gold coins were minted in Carthage. Solidi minted in Byzantium dominate the hoard finds from Vandal North Africa. ${ }^{28}$ Among all the fifth-century regna that were established in the Roman empire, only Ostrogothic Italy developed 'a fully formed monetary system with all three metal types'. ${ }^{29}$ In contrast to the Vandals, the Ostrogoths minted three denominations in gold: solidi, semisses $(1 / 2$ solidus) and tremisses $(1 / 3$ solidus $)$. Most of these gold coins were struck in the name of Eastern emperors: Zeno, Anastasius, Justin and Justinian I. On a few of them we also find Theoderic's monogram, or a $\Theta$ (THeodericus) at the end of the legend on the obverse..$^{\circ}$

The profits from the corn, oil and garum trade with Italy and the wider Mediterranean brought gold to Africa. ${ }^{31}$ The delivery of the annona from the African provinces probably ceased, at the latest after the Vandal occupation of Carthage under Geiseric. This factor alone improved the trade capacity of the Vandal kingdom. ${ }^{32}$ However, between 442 and 455, after Geiseric's treaty with Valentinian III and before the death of the emperor, grain was shipped to Rome in a way similar to the annona. ${ }^{33}$ Owing to recent archaeological and economic studies we can trace the basic tendencies of the Vandal economy, ${ }^{34}$

27 See in general M. McCormick, Origins of the European Economy. For the circulation of gold coins in Africa see Morrisson, La circulation de la monnaie d'or en Afrique, pp. 325-44.

28 Mostecky, Münzen zwischen Rom und Byzanz, p. 86 and n. 77 presents an extensive collection of mass finds of gold coins between the fifth and the seventh centuries in North Africa. The Musée de Bardo preserves a tremissis with a barbarized Honorius legend and a cross within a wreath on the reverse. These coins do not prove Vandal gold coin minting. See Morrisson, 'Les origins', p. 462 and Morrisson, Caratteristiche ed uso della moneta protovandalica e vandalica, p. 160 and n. 7. See further Hendy, Studies in the Byzantine Monetary Economy, pp. 478-9. Hendy does not exclude gold minting, but considers as doubtful the conventional assignments.

29 Hahn, Moneta Imperii Byzantini I, p. 77: 'ein ausgebildetes Währungssystem in allen drei Metallen'.

3o E.T. Fort, 'Barbarians and Romans: The Mint of Rome under Odoavacar and the Ostrogoths AD 476-554', Proceedings of the Western Pennsylvania Numismatic Society 1 (1994), pp. 19-3I, gold: pp. 25-7; J.P.C. Kent, 'The Coinage of Theoderic in the Names of Anastasius and Justin I', in R.A.G. Carson (ed.), Mints, Dies and Currency (London, 197I), pp. 67-74. Examples of monograms: Wroth, BMC Vand, p. I4, nn. 64-6 and Theta: Wroth, BMC Vand, p. 15, n. 63.

${ }_{31}$ Grierson, MEC, p. 19.

32 S. Reynolds, 'Hispania in the Late Roman Mediterranean: Ceramics and Trade', in K. Bowes and M. Kulikowski (eds), Hispania in Late Antiquity: Current Perspectives, The Medieval and Early Modern Iberian World 24 (Leiden and Boston, 2005), pp. 369-486, here pp. 418-26.

33 Procopius, Bellum Vandalicum, III.iv.I3, Procopius, with an English Translation by H.B. Dewing, Loeb Classical Library 8I (Cambridge, MA and London), p. 39.

34 P. v. Rummel, 'Zum Stand der afrikanischen Vandalenforschung', Antiquité tardive 11 (2003), pp. 13-19, here pp. I6-18, presents a current overview. See also N. Duval, L. Slim, M. Bonifay, J. Piton and A. Bourgeois, 'La céramique africaine aux époques vandale et byzantine', Antiquité tardive 10 (2002), pp. 177-95. 
including its prosperity. For example, the study of a sample of ceramics from the second half of the fifth century in the city of Rome, shows that up to $90 \%$ of the fine tableware had been produced in North Africa. ${ }^{35}$ M. Mackensen even postulated a Mediterranean monopoly of North African high-quality ceramic production in the Vandal period. ${ }^{36}$ Recently, F.L. Sánchez explained the surprisingly high number of solidi and bronze coins that were found in the south-west of the Iberian peninsula and which are datable to the end of the fifth and the beginning of the sixth century, as a sign of good commercial contacts with VandalAlanic North Africa. ${ }^{37}$

One of the reasons for Justinian's re-conquest of the North African provinces in 533/4 was arguably its prosperity. Ph. von Rummel recently confirmed this on the basis of the archaeological evidence. ${ }^{38}$ Procopius explicitly mentions North Africa's wealth:

As furthermore they lived in a wealthy and extremely fertile country that produced all life's necessities in abundance, they did not need to use their profits for the purchase of food from other regions, but, as owners of their estates, could accumulate them over the period of the ninety-five years during which they governed Libya. ${ }^{39}$

The Vandals also acquired large sums on their numerous raids in the western and eastern Mediterranean during the reign of Geiseric. ${ }^{40}$ Not only gold, but also prisoners came to Africa, who again could be turned into money. The imprisonment of members of the Carthaginian aristocracy in 439 had been a first sign of this activity. ${ }^{41}$

35 C. Panella and L. Saguì, 'Consumo e produzione a Roma tra tardoantico e altomedioevo: Le merci, I contesti', in Roma nell'alto medioevo, Settimane di studio del centro italiano di studi sull'alto medioevo 48. Spoleto 27 aprile - I maggio 2000 (Spoleto, 200I), pp. 757-820, here p. 779; M. Fulford, 'Carthage: Overseas Trade and the Political Economy c. AD 400-700', Reading Medieval Studies 6 (1980), pp. 68-80, here pp. 68-70.

${ }_{36}$ M. Mackensen, Die spätantiken Sigillata- und Lampentöpfereien von El Mahrine (Nordtunesien). Studien zur nordafrikanischen Feinkeramik des 4. bis 7. Jahrhunderts (Munich, I993).

37 F.L. Sánchez, 'Coinage, Iconography and the Changing Political Geography of Fifth-Century Hispania', in K. Bowes and M. Kulikowski (eds), Hispania in Late Antiquity: Current Perspectives (Leiden and Boston, 2005), pp. 487-518, here p. 517.

38 Von Rummel supported this view in a paper delivered at the International Medieval Congress at Leeds in 2005. Rummel's arguments were based on: S.J.B. Barnish, 'Pigs, Plebeians, and Potentes: Rome's Economic Hinterland c.350-600 AD', Papers of the British School at Rome 55 (1987), pp. I37-85.

39 Procopius, Bellum Vandalicum IV.iii.26, ed. Dewing, p. 235.

$4^{\circ}$ Courtois, Les Vandales, pp. 185-205; S. De Souza, Piracy in the Graeco-Roman World (Cambridge, 1999), pp. 23I-8.

${ }^{4}$ This is illustrated in a letter of Bishop Theodoret's, who describes the case of a certain Maria who was ransomed by her father after a long period of imprisonment: Theodoret, Ep. 70, ed. Y. Azéma, Sources Chrétiennes 98 (Paris, I964), p. 67 (dated c.440 AD). 
The booty from the two-week ransack of the city of Rome in 455 is mentioned in detail in our sources. ${ }^{42}$ Procopius reports that Geiseric carried off large amounts of imperial gold on his ships. The Vandals even tore down the roof of the temple of Iuppiter Capitolinus, in order to bring the bronze and its gold overlay to Carthage. We should also briefly mention an anecdote reported by Victor of Vita: Deogratias, bishop of Carthage, commiserated with the many hostages whom the Vandals brought from Rome to Africa. As Victor explains with contempt, these people were - according to 'barbaric custom' - already classified by age and abilities, in keeping with their 'market value'. ${ }^{43}$ The bishop sold golden and silver liturgical objects, in order to pay large sums of ransom to the Vandal king. Christian compassion was, however, restricted to freeborn prisoners. ${ }^{44}$

After the defeat of the Vandals in the battle of Trikamaron, the victorious Byzantines took the dead soldiers' objects of value and occupied their field camp: 'The amount of objects of value that the Romans found in the camp was incomparable, as the Vandals over a long period had continuously robbed the Roman Empire and taken many treasures to Libya.' ${ }^{45}$

\section{Royal Vandal silver coins}

The Vandal coins come in two forms: coins that feature a royal name, and those that do not mention the lord of the mint. In addition, we know of pseudo-imperial coins with the right-sided profile of the western emperor Honorius, from the time of Gunthamund. The issue of silver coins with a royal name begins under Gunthamund and ends with the last king, Gelimer. ${ }^{46}$ Each Vandal king in this period issued a complete series, from 50 denarii in silver up to a copper coin with the value of 4 nummi. However, a silver coin with the value of Ioo denarii and a weight of $c .2 \mathrm{~g}$ is only known from the period of Gunthamund. Scholars have regularly returned to the investigation of the fifty years between the invasion of Geiseric's Vandals in North Africa and the issue of the

${ }^{42}$ Prosper Tiro, Chronicon 1375, ed. Th. Mommsen, MGH AA 9, Chronica Minora I (Berlin, I892; repr. 198I), p. 484: secura et libera scrutatione. Further sources are collected in Courtois, Les Vandales, p. I95, with nn. 8-IO; D. Henning, Periclitans res publica. Kaisertum und Eliten in der Krise des weströmischen Reiches 454/5-493 n. Chr. (Stuttgart, 1999), pp. 20-7.

43 Courtois, Les Vandales, p. I95: 'Les objets n'avaient point été chosis sans discernement et pas davantage le bétail humain. On avait tenu compte des aptitudes et de l'âge - de la valeur marchande, pour parler clair.'

44 Victor Vitensis, Historia Persecutionis Africanae Provinciae I.25, ed. M. Petschenig, CSEL 7 (Vienna and New York, I88I), p. I3.

45 Procopius, Bellum Vandalicum, IV.iii.25 and 26, ed. Dewing, p. 233.

${ }_{46}$ We can assign the following coins to individual Vandal kings: Gunthamund: nos. 5-7; Thrasamund: nos. 9-II; Hilderic: no. I5; Gelimer: no. 19. Only no. 8 is uncertain. 
first-known siliquae under Gunthamund (484-96). In this context we need to remind ourselves of the coinage in other fifth-century regna within the Roman empire. The Visigoths and Sueves in Spain only started to issue coins after 580, while the Franks minted for a period after 534, and the Burgundians after 473; all therefore started long after establishing their regna. ${ }^{47}$ Meanwhile in Italy, Odoacar continued the Roman system under agreement with the Roman senate. The Vandal and Ostrogothic attempts to create a functioning monetary system may therefore have been especially influential in shaping future systems. Michael Hendy considers the Vandal and Ostrogothic example as the 'immediate source of inspiration for the imperial monetary reform of $498^{\prime} .{ }^{8}$ We can draw less precise conclusions about the coins of the Sueves, who had invaded the Roman empire alongside the Vandals at the beginning of the fifth century and established a regnum in the north-west of the Iberian peninsula. Owing to the diffused nature of our evidence, their history is unclear ${ }^{49}$ - we cannot even compile a complete list of kings for the period of their presence in Spain. We know of the coins of only two Suevic kings: Rechiarius (438-55) and Audeca (584-5), who both issued silver coin series. The form of their tremisses was modelled on those of Emperor Valentinian III..$^{\circ}$ The Sueves, therefore, also did not create a new monetary system, but apparently were interested in uninterrupted trade opportunities with other parts of the empire.

North African Vandal coins imitating those of Honorius can be divided into two groups..$^{\text {s }}$ The coins of the first group represent a sitting Roma on the reverse, with the legend VRBS ROMA. The coins of the second group display a date on the reverse: Anno IV or V K, the $\mathrm{K}$ standing for Karthaginis, which is usually interpreted as a sign for the mint in Carthage. The completion of the date is more problematic. Friedländer, Wroth and Hahn assigned this coin type to King Huneric. The first two authors based their conclusions on a reading of the legend as HONORICVS, rather than HONORIVS. Hahn argued for Huneric instead, on the basis of the reference to indiction years on fifth-century

47 See Morrisson, Caratteristiche ed uso della moneta protovandalica e vandalica, p. I56; S. Suchodolski, 'Les débuts du monnayage dans les royaumes barbares', Mélanges de Numismatique d'archéologie et d'histoire offerts à Jean Lafaurie (Paris, 1980), pp. 249-56.

48 Hendy, Studies in the Byzantine Monetary Economy, p. 490.

49 M. Schönfeld, 'Suebi', in RE IV A, I (193I), pp. 564-79; O. Wendel, 'Das Suevenreich auf der Pyrenäenhalbinsel', Zeitschrift der deutschen Geisteswissenschaften 5.I (1942), pp. 306-I3; R. Reynolds, 'Reconsideration of the History of the Suevi', Francia 6 (1978), pp. 647-76; N. Wagner, 'Die Personennamen als Sprachdenkmäler der iberischen Sueben', in Erwin Koller and Hugo Laitenberger (eds), Suevos-Schwaben: Das Königreich der Sueben auf der Iberischen Halbinsel (4II-585) (Tübingen, 1998), pp. 137-50.

so Grierson, MEC, p. 78 .

sI The Vienna collection contains four examples: nos. I-4. 
Italian coins, for under Huneric the dates of his reign match indiction years. Furthermore, Huneric's son Hilderic, when issuing his silver coins, returned to the type of reverse with Carthage carrying a corn ear. ${ }^{52}$ Morrisson and Schwartz suggested a $480 / \mathrm{I}$ and $48 \mathrm{O} / 2$ date, above all on the basis of stylistic considerations. ${ }^{33}$ Clover believed on the evidence of epigraphic comparanda that the annual dating was a dating according to eras of reign, and assigned the coins to Geiseric. According to this calculation, the coins in question would be dated to $442 / 3$ and $443 / 4 .^{54}$

There are no silver coins whose legends mention the names of the two Vandal kings Geiseric and Huneric. Therefore we can assume that only during the reign of Gunthamund did royal names start to be struck on coins, a habit that we can subsequently trace up to Gelimer's reign." At this time the only royal monogram from a Vandal context appears on a copper coin..$^{6}$

Spelling of the royal names on the portrait coins differs considerably. In a few cases we find the abbreviation DN (Dominus noster) that is also attested in epigraphy, to which sometimes REX is added." The Vandal coins usually feature a value mark on the reverse, ${ }^{58}$ surrounded by a wreath that closes on a dot or a cross. ${ }^{9}$ Hilderic, furthermore, had coins minted that replaced the value mark with the representation of a standing Carthage. This figure holds either corn ears, or branches, or flowers. The legend on these silver coins is FELIX KART[HA]G[O].60

52 Hahn, Moneta Imperii Byzantini I, p. 93 and W. Hahn and B. Woytek, Review of RIC X, Numismatic Chronicle (1996), p. 392.

53 C. Morrisson and J.H. Schwartz, 'Vandal Silver Coinage in the Name of Honorius', American Numismatic Society Museum Notes 27 (1982), pp. 177-80. Morrisson, 'Les origins', p. 469 had not yet established assignment to Gunthamund (that is, the years $487 / 88$ ) or Huneric (480/I and $48 \mathrm{I} / 2$ ).

54 Clover, Felix Karthago, pp. 3-I6. See also N. Schindel's argument in 'Die erste germanische Münze?', Money Trend 12 (1998), pp. 55-7, where, again on the basis of epigraphic comparanda, he assigns the coins to the time of Huneric. This view is supported by the stylistic closeness of the bust in profile to the chronologically succeeding coins that can clearly be assigned to Gunthamund.

ss The end of siliqua imitating those of Honorius occurs during Gunthamund's reign: Morrisson and Schwartz, Silver Coinage, p. 177: 'Silver coins signed by Gunthamund (484-96) finish this imitative series.'

56 No. 20. Regler believes to have identified a further monogram of Gelimer: see H. Regler, 'Ein unbekanntes Gepräge des letzten Vandalenkönigs Gelimer (530-533)', Berliner Numismatische Zeitschrift (1954), pp. 75-7. However, this coin is a forgery.

57 There are the following variants: DN RX, DN RG: the genitive form Domini Nostri Regis.

58 See the discussion of the value marks in the section on copper denominations.

59 On the coins of Gelimer, however, only a simple wreath appears on the $1 / 2$ siliquae, as it had done on Hilderic's last $1 / 4$ siliquae. See Hahn, Moneta Imperii Byzantini I, p. 95.

60 The legend probably follows the imitative Honorius siliquae, which likewise presents a standing Carthage holding corn ears on the reverse. See Schindel, Die erste germanische Münze?, p. 55 . 


\section{The problem of the two Vandal copper series and their value system}

Copper coins probably represented the most common currency in dayto-day transactions, where these included monetary exchange. Grierson considered the Vandal copper coins in two series to be of municipal origin, while most scholars agree that they were royal coins. ${ }^{61}$ They consist of four denominations: XLII, XXI, XII, and IIII nummi. Detailed discussion of these copper series is important, because it is on their basis that scholars have continuously tried to explain the value system of Vandal coins. Furthermore, the categorization of imperial incised bronze coins also depends on the interpretation of the copper denominations. In the following discussion we will consider two different explanations of the Vandal coinage system.

Grierson and Hendy agree on the following system: the denarius was originally designed as a unit with ten subordinated units or nummi. The Vandal silver coins are inscribed with $D N L$; that is, a value of 50 denarii. The silver coins from the time of Gunthamund and the first years of Thrasamund's reign lack an indication of the value next to the abbreviation $D N$. This demonstrates that it was self-evident to consider this siliqua as a 50 denarius, with the value of Ioo nummi. The coin of 50 denarii is accepted as siliqua, while the coins of Ioo denarii and of 25 denarii were consequently of double or half value. Under this system, the solidus would have had a value of 1,200 denarii and therefore 12,000 nummi. The markings of 42 and 2I on the copper coins, in this way would have indicated a twelfth or a twenty-fourth of a siliqua; while the smaller copper values inscribed with XII would have been a thousandth of a solidus, and with IIII a thousandth of a tremissis. As is well known, the solidus had a weight of $4.5 \mathrm{~g}$ of gold $\left(1 / 7_{22} \mathrm{lb}\right.$ of gold) and could be converted into twenty-four siliquae (with one siliqua weighing $2.3 \mathrm{~g}$ of silver). The tremissis was struck with a weight of $\mathrm{I} .5 \mathrm{~g}$ of gold. ${ }^{62}$ Grierson's argument rests on the basis of two mints: on the one hand, the Vandal kings used to strike silver coins; on the other, the magistrate of Carthage issued the copper coins. Grierson draws this conclusion from the fact that none of the copper coins features a royal symbol. As mentioned above, we know of two Vandal copper coin series. The first shows a standing Carthage on the obverse, holding corn ears in her hands, and the letter $N$ (for nummi) on the reverse. This series is known with the denominations of XLII, XXI and XII nummi. The second series has the same denominations, but the obverse presents the inscription Karthago

${ }_{61}$ Grierson, MEC, p. 19 and 2I. A similar argument is already to be found in Friedländer, Münzen, pp. 8-I2.

62 M.F. Hendy, Studies in the Byzantine Monetary Economy, pp. 480-2. 
and a standing warrior. On the reverse is stamped a horse head and the coin's value (but no $N$ ). Furthermore, this series includes a piece of four nummi that has a left-sided male bust holding a palm tree branch on the obverse, and the numeral sign N IIII on the reverse. Grierson was convinced that this coin type should be assigned to the second series, as the letter $N$ is added to the value, but the characteristic wreath is absent in the first series. ${ }^{63}$

In other provinces of the Roman empire and in Ostrogothic Italy, coins were often minted as multiples of the nummus (for example, as pentanummia). These coins were relatively late additions to the imperial coin system, which were often issued by urban magistrates. It is possible that curial authorities had acquired a right to mint bronze coins of higher value, although the issue of nummi traditionally was reserved to the emperor, or the kings. Grierson therefore thought that the mint in Carthage was unsure about how to handle a IIII-nummus coin, as its worth fell between the established values. Grierson needs to explain the value of the IIII-nummi coins as he believes Vandal coinage to have been based on the value of I-nummus. A related problem is the variation in weight of the IIII-nummi piece in the two coin series: in the first series it weighs $5 \mathrm{~g}$, in the second $4.5 \mathrm{~g} .{ }^{64}$

Hahn instead postulated the $1 / 2$ siliqua as the main Vandal coin, and assumed that one siliqua had a value of Ioo denarii. The siliqua is a coin struck in fine silver with a value of $1 / 24$ of a solidus that had been introduced by Constantine. There is scholarly consensus about

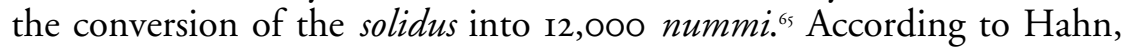

${ }_{33}$ Friedländer, Münzen, p. 39; Wroth, BMC Vand, p. 7, nos. I2-I4; Grierson, MEC, p. 2I and nos. 34-50.

${ }^{64}$ Grierson, MEC, pp. 22-3.

6s However, on the basis of the Albertini tablets the relation of the solidus to the nummus was established as $\mathrm{I}=14,400$. Hahn considers this to be the highest rate of exchange before the reform of Anastasius. See Hahn, Moneta Imperii Byzantini I, p. 92. The following reflections about the rate of exchange between the follis and solidus were made on the basis of a sale contract dating to 494: A slave is sold for 'auri solidum unum et folles septingentos aureos obbrediacos ponderi plenos numero unum semis'. Courtois believed the value of the solidus to be double that of the mentioned semis, that is, I, 400 folles. See C. Courtois et al., Tablettes Albertini Actes privés de l'epoque vandale (Paris, 1952), p. 203. Grierson replied that a Vandal nummus value of XLII resulted in a value of $42 \times 1400=58,800$, which would be unrealistic. He proposed instead to read semis as semuncia, that is, $1 / 2$ ounce of gold. This meant that the solidus, which was minted as a $1 / 6$ of an ounce al pezzo, was worth $14,700(350 \times 42)$ nummi. See P. Grierson, 'The Tablettes Albertini and the Value of the Solidus', pp. 73-80. Morrisson interprets the follis as a unit of account, with a rate of exchange of I solidus = I400 folles. See Morrisson, 'Les origines', pp. 464-5 and the summary in Morrisson, Caratteristiche ed uso della moneta protovandalica e vandalica, p. 152 . We always need to consider that the expression of the value of the solidus in nummi varied significantly in the fifth century, from 7,200 in the midcentury to 14,400 in the 490 os. The movement of inflation was, according to Grierson, at least partly caused by the uncontrolled issue of small bronze coins and only the empire-wide reform of Anastasius in 498 brought it back under control. See Grierson, 'The Tablettes Albertini and the Value of the Solidus', p. 8o, and our own conclusions below. 
the Vandal coin system knew I siliqua, as well as $1 / 2$ and $1 / 4$ siliquae, with silver and bronze values of 42, 2I, I2, 4 and 2 nummi. This system hence resulted in a value structure of one siliqua $=100$ denarii, $1 / 2$ siliqua $=50$ denarii, and $1 / 4$ siliqua $=25$ denarii, while one siliqua had a value of 500 nummi. The main currency was $1 / 2$ siliqua, which could be exchanged for five XLII nummi and ten IIII nummi, as well as for ten XXI nummi and ten IIII nummi. Hahn draws his conclusion about these coin values on the basis of his metrological reflections about the standard heavy silver content under Huneric ( $1 / 2$ siliqua was $1 / 240 \mathrm{lb}=\mathrm{I} .63 \mathrm{~g}$ ). Under Gunthamund and Thrasamund, however, we witness a lighter standard silver content (with the $1 / 2$ siliqua weighing $1 / 288 \mathrm{lb}=\mathrm{I} . \mathrm{I} 4 \mathrm{~g}$ ). According to Hahn, Hilderic and Gelimer returned to the original heavy standard. Most Vandal silver coins display the value mark L for the $1 / 2$ siliqua. This copper denarius is easily converted into 2.5 nummi, resulting in a Vandal copper coin system with the grades of LXXXIII (according to Hahn), XLII, XXI, XII and IIII nummi, which can be understood as $1 / 3$, $1 / 6,1 / 12,1 / 24$ and $1 / 72$ of the siliqua with the value of 250 nummi. ${ }^{66}$ Hahn further postulates a common relationship between metals in the west of the Roman empire, with one solidus equalling $\mathrm{I} 6 \mathrm{lb}$ of copper. The Vandal follis, as a consequence, equals $1 / 6$ of the $1 / 2$ siliqua, which in turn corresponds exactly to the heavy standard silver content of the Vandal kings. ${ }^{67}$ Gunthamund does not seem to have minted his own folles, but used older incised coins. Originally the big copper coins of Diocletian's coin reform in the late third century were called follis. Until Anastasius's coin reform the term follis, however, is of uncertain use. With this account Hahn delivered another implicit argument for the late dating of the Vandal copper series to the period after Anastasius's reform.

The silver coins issued by Gunthamund and Thrasamund, which according to Hahn were minted with the above-mentioned light standard, display the same value mark in copper units (that is nummi). On the basis of this we should expect a change in the standard of metal content of the copper coins. Hahn, however, commented that 'The two Vandal copper series are based on the same standard, and therefore are either contemporary with the light or with the heavy standard silver content,

66 There is, however, a sestertia with the mark LXXXIII.

${ }^{67}$ For the Vandal copper coins this means: I follis $={ }^{1} / 18 \mathrm{lb}, 288$ folles (at 42 nummi each) $=\mathrm{I}$ solidus. In Hahn's system a solidus corresponds to ${ }^{288} / 6=48$. The Vandal folles were therefore very underweight, while their content was of superior quality. Hahn assumes the standard weight of $\mathrm{I}$ follis $\left(\right.$ at 42 nummi) $=\mathrm{I} 8.19 \mathrm{~g} ;{ }^{1} / 2$ follis $($ at $2 \mathrm{I}$ nummi $)=9 . \mathrm{I} \mathrm{g} ;{ }^{1} / 4$ follis $(\mathrm{I} 2$ nummi $)=$ $5.20 \mathrm{~g} ; 4$ nummi $=\mathrm{I} .73 \mathrm{~g}$; and the copper denarius $=\mathrm{I} .09 \mathrm{~g}(2 \mathrm{1} / 2$ nummi $)$. See Hahn, Moneta Imperii Byzantini I, pp. 9I-3. 
but not with both.' ${ }^{68}$ Hahn's metrological analysis further leads to the conclusion that the two copper series are roughly based on the same metal standard as the Italian folles and those of the imperial government after 512. However, there is a slight shift owing to the fact that the Vandal follis that Hahn has calculated had a value of 42 rather than 40 nummi.

The Vienna collection also includes minimi (denarii and 4-nummi pieces), which, Hahn argues, replaced the imperial semi-centenionales in money exchange. Centenionales were bronze values from the currency reform of Constans and Constantius II, the sons of Constantine, in the mid-fourth century, and were issued in whole and semi-pieces. Hahn criticizes the traditional dating of the Vandal copper as based on a series of assumptions. He instead assigns the two copper series to the two last Vandal kings, Hilderic and Gelimer.

In paticular, the standing warrior with a spear on the reverse of the second series has often been assigned to King Geiseric. We have to reject this, however, for metrological reasons, and the assignment is not repeated in more recent numismatic publications. ${ }^{69}$ In many cases, the reverse of the coins present a horse head, which is usually interpreted as a personification of Carthage ${ }^{7^{\circ}}$ and has been seen by scholars as Geiseric's deliberate provocation of Rome. By referring to old, Punic symbols, the great Vandal king would have sent a powerful message across the sea. ${ }^{11}$ However, we have to note that this iconography also appears in Carthaginian mints during Justinian's time. As a parallel representation of Carthage on Vandal silver coins, we also know a female figure carrying a corn ear. ${ }^{72}$ The Ostrogoths also used a similar reference to traditional icons when they represented the lupa Romana on their coins struck in Rome. ${ }^{73}$ Clover, in turn, interprets the figure of Carthage on the obverse of the first copper series as related to this lupa.

68 Hahn, Moneta Imperii Byzantini I, p. 92.

69 Yet it is still repeated in modern surveys of the period, such as V. Postel, Die Ursprünge Europas. Migration und Integration im frühen Mittelalter (Stuttgart, 2004), pp. I86-7.

70 Nos. 24-26. For their interpretation see Clover, Felix Karthago, pp. 3-4.

${ }^{71}$ See H. Wolfram, Das Reich und die Germanen. Zwischen Antike und Mittelalter, Siedler Deutsche Geschichte I (Berlin, 1992), p. 24I, who, in a figure caption, speaks of 'reuse of pre-roman, even anti-roman tradition by the Vandals' ('Wiederaufnahme vorrömischer, ja antirömischer Tradition durch die Vandalen').

72 Friedländer, Münzen, pp. 36-7 gives the following interpretation: 'Eher stellt diese Figur den König in römischer Tracht dar, wie er auch in allen Brustbildern der Vorderseite erscheint; einen Helm trägt er nicht. Der Pferdkopf der Kehrseite der ersten Reihe ist wohl von den antiken Münzen von Karthago überkommen, die man gewöhnlich auch Panormus zutheilt. Dort bezieht er sich auf den bronzenen Pferdkopf welche die Gefährten der Dido bei der Gründung Karthago's gefunden hatten. Dieser Pferdkopf auf den antiken Münzen ist stets ohne Zaum, auf den vandalischen bald mit, bald ohne Zaum. Man möchte denken der Zaum bedeute, die Vandalen hätten das karthagische Ross gezügelt. So hat Napoleon das welfische Ross auf einer Medaille gezügelt dargestellt.'

73 See Hahn, Moneta Imperii Byzantini I, p. 89, nos. 70 and 7I. 
It may have been issued on the occasion of the peace treaty between Geiseric and Odoacre in $476 . .^{74}$ The most probable conclusion is that there existed continuity in the use of local Carthaginian symbols in the mint of the Vandal kings.

In 1998 Schindel assigned the so-called Domini Nostro series to Geiseric. This series is a group of minimi that feature the late antique imperial title DN in three versions (Domini Nostro, Dominis Nostris, Dominorum Nostrorum) and in this way differ from all other fifth-century coins. Previous scholars had regarded Bonifatius as the lord of the mint, but Schindel argued that the commander Bonifatius would have had little interest in small coins, as soldiers were paid in gold and silver coinage. According to Schindel, the issue of Domini Nostro pieces occurred in the period between 440 and 450 and may have had something to do with the treaty between Geiseric and Valentinian III in 442. ${ }^{5}$

\section{The countermarked imperial bronze coins}

We will now turn to those incised bronze coins that can be assigned to a Vandal context. The part of the collection of the Kunsthistorisches Museum under investigation here includes ten imperial dupondi and asses. Almost all of these originate from the mint of the Flavian dynasty. ${ }^{76}$ These feature a number of different incisions with the value mark of XLII, the quality of which varies substantially. The mark is usually placed on the obverse without damaging the emperor's bust. Morrisson has already noted this peculiarity of the incisions. ${ }^{77} \mathrm{We}$ also find it on a coin in the Viennese collection that presents the numeral sign $\mathrm{L}$ the wrong way around. ${ }^{78}$

Morrisson has assumed that these scratched bronze coins were an addition to the first Vandal copper series (indication of value on the reverse and the same personification of Carthage on the obverse, as on

74 F.M. Clover, 'Relations between North Africa and Italy A.D. 476-500: Some Numismatic Evidence', Revue Numismatique 33 (I991), pp. II2-33.

75 Schindel, Die erste germanische Münze?, p. 57.

76 Nos. 35-44.

77 See C. Morrisson, 'The Re-Use of Obsolete Coins: The Case of the Roman Imperial Bronzes Revived in the Late Fifth Century', in C. Brooke (ed.), Studies in Numismatic Methods Presented to Philip Grierson (Cambridge, 1983), pp. 95-7. We also have evidence, although not in the Viennese collection, for incisions of the value of LXXXIII nummii.

${ }^{8}$ The $\mathrm{L}$ on the obverse of no. 40 is scratched the wrong way around. It is this piece and no. 35 about which Morrisson, 'Re-Use', comments: 'On two coins in Vienna the figures are scratched as the reverse as well as the obverse (pl. IO, no. II), presumably the engraver's carelessness.' This may be the case for no. 40, but there is confusion regarding no. 35. Morrisson calls the coin 'Vespasian for Titus' and dates it to AD 72. The coin, however, has the legend DOMITIAN COS II [ on the obverse and probably only one incision, which is difficult to see. The coin was scratched on the reverse, in order to avoid damage to the emperor's bust on the obverse. 
Huneric's silver denarii). She is able to show, on the basis of archaeological evidence and stocktaking in many museums, that such coins were found more often in Italy than in North Africa, which she links to the transferral of troops at the end of the Vandal reign by the Byzantine general Belisarius. Mostecky furthermore suggests that these coins were issued by displaced Vandals on the way back into their northern 'homeland'. This last hypothesis has to be rejected as pure speculation. ${ }^{79}$

Throughout antiquity, copper and bronze from old coins still in circulation were continuously melted and reused. From this stems the varying purity of the copper coins, which probably included much of the metal originally used to strike imperial bronze coins. ${ }^{80}$ The reuse of imperial emissions during the Vandal age confirms both the general metal value of these coins, and that their circulation spanned many centuries. Another theory interprets the scratched bronze coins as predecessors of an independent Vandal coinage. ${ }^{8 .}$ Alongside the imitative Honorius coins, the scratched coins may therefore have been the first attempts to establish the later currency system.

\section{Conclusion}

The collection of Vandal coins in the Kunsthistorisches Museum provides us with a representative cross-section over the entire period of Vandal minting activity. The imitative Honorius coins and perhaps also the scratched imperial bronze coins represent a first step in the attempts of the Vandal kings to guarantee a unified and functional currency system within their territory, in order to deal with the problems of the imperial currency that arose from the lack of silver and higher copper values in the second half of the fifth century. All Vandal coins were related to the imperial solidus, for Vandal coinage activity was never meant as an independent currency system. The royal silver denarii

79 Morrisson, 'Re-Use', pp. 99-IOI; H. Mostecky, 'Zur Datierung der von den Vandalen kontermarkierten römischen Gross- und Mittelbronzen', Mitteilungen der Österreichischen Numismatischen Gesellschaft 26.I (1986), pp. IO-II. Mostecky uses the term 'Fluchtgeld' - money minted on the run.

so C.E. King et al., 'Copper-Based Alloys of the Fifth Century. A Comparison of Carthage under Vandalic Rule with Other Mints', Revue Numismatique, V ${ }^{\text {ie }}$ série 34 (I992), pp. 5476 , analyses the metal content of the two Vandal copper series with the following conclusion: the first series with the corn-carrying Carthage possesses a higher percentage of lead and a lower one of copper, while the coins of the second series, with the standing warrior on the obverse, contain almost no lead but much copper and tin. The authors stress, however, that they were able to analyse only twelve coins.

8I Hahn, Moneta Imperii Byzantini I, p. 94: 'Darin haben wir die Vorläufer des späteren eigenen Kupfersystems zu sehen.' 
and the two copper series were supposed to complement the imperial currency in the African provinces.

Vandal coinage can serve to help us understand the political and economic structures of the regnum. The Vandal kings issued coins that represented them as having an extraordinary position. This was without doubt important propaganda, which was certainly effective, especially in the African provinces. Barbarian regna are to be interpreted on the basis of their individual conditions. Terms such as 'state', 'autonomy' or 'sovereignty' are anachronistic. Better are recent working titles, such as 'kingdoms within the empire' or barbarische Nachfolgereiche, which make obvious that barbarians provided a military elite but did not aim to change the late Roman system - indeed, were part of that system. Integration and transformation replace the exaggerated emphasis on military and political events. ${ }^{8_{2}}$

We can only talk to a certain extent about imitatio imperii where Vandal coins are concerned, as Vandals did not issue their own gold coins with the accompanying representation of the ruler. ${ }^{83}$ However, the silver denarii of the Vandal kings at least picture them with diadem and paludamentum. In contrast to the Ostrogoths, after the imitative Honorius issues, the Vandals never mentioned the Roman emperor again on their coinage. We can therefore postulate a certain independence of the iconography on Vandal coins.

The largest part of the coin finds from the North African regnum are copper (minimi). Their assignment is problematic due to the lack of clear names in the legend..$^{{ }_{4}}$ Alongside these copper coins and the royal silver coins, further gold and silver coins circulated that showed traditional representations of the ruling Roman emperor of the time. Because of confiscation of church and private property during the invasion, the Vandal royal treasury had acquired large amounts of gold

82 For a different view on this question see, for example, Wolfram, The Roman Empire and its Germanic peoples, pp. 242-4; H. Schutz, The Germanic Realms in Pre-Carolingian Central Europe 400-750, American University Studies, Ser. IX History, Vol. 196 (New York, 2000), pp. 45-7; Pohl, Die Völkerwanderung, pp. 30-9; W. Pohl, 'Justinian and the Barbarian Kingdoms', in M. Maas (ed.), The Cambridge Companion to the Age of Justinian (Cambridge and New York, 2005), pp. 448-76.

83 Yet, Huneric renamed the city of Hadrumetum (present-day Sousse) in Hunericopolis, which is a clear reference to imperial examples.

${ }^{84}$ A. Ben Abed and N. Duval, 'Carthage, la capitale du royaume et les villes de Tunisie à l'époque vandale', in G. Ripoll and J.M. Gurt (eds), Sedes regiae. ann. 400-800 (Barcelona, 2000), pp. 163-218, here p. I66: 'La qualité en [Vandal coinage] est mauvaise et la masse monétaire est formée de minuscules rondelles (appelées dans l'usage moderne minimi) de cuivre informes marquées de quelques signes ...'; see also the introduction to an extensive new acquisition of coins, including some Vandal copper coins, in B. Kluge, 'Römer, Goten und Vandalen. Numismatische Zeugnisse der Völkerwanderungszeit. Zu einer Neuerwerbung', Museumsjournal. Berichte aus den Museen, Schlössern und Sammlungen in Berlin und Potsdam 3 (1994), pp. 64-7 with Plate 7. 
that could either be used to pay or reward soldiers, or be employed in the context of royal representation. In 455, when the Vandals, together with the Alans and Berbers, pillaged Rome for fourteen days, they brought back to Africa the contents of imperial palaces and the west Roman treasury, as well as the gold, silver and bronze stock of the city's moneta. ${ }^{85}$ Furthermore, we need to take into account the ransom paid for captured Romans. These precious metals as well went towards the minting of Vandal coins. It would be interesting to explore whether the pillagers from 455 attempted to resolve the currency crisis in their territory that occurred thirty years later, with exactly these precious metals brought from Rome.

In the first instance, the Vandal kings sought a relationship with the western empire governed from Ravenna; later, especially under Hilderic, they turned to Byzantium. ${ }^{86}$ The Vandal kings, who tried to establish their regnum as a third power in the Mediterranean alongside the western and eastern empires, needed a solid financial system. The political, administrative and economic structures of the Vandal kingdom were definitely not primitive. In Carthage the Vandals had access to a legal and technical knowledge that was of the highest quality. It is evident from the sources that Roman experts occupied high positions within the administration of the African provinces under Vandal rule. ${ }^{87}$ The coinage also displays this high quality.

The administration of the Vandal kings needed money. In the second half of the fifth century there was a lack of circulating money of middling denominations, and inflation affected the entire Roman empire. It is exactly in this period that we can observe the attempts to create a functioning currency system. The basis was always the imperial currency

${ }^{85}$ Henning, Periclitans res publica, p. 262.

86 F.M. Clover, 'Geiseric the Statesman: A Study in Vandal Foreign Policy', Ph.D. thesis, University of Chicago (1966), p. 209; G. Wirth, 'Geiserich und Byzanz. Zur Deutung eines Priscusfragments', in Nia A. Stratos (ed.), Byzantium: Tribute to Andreas N. Stratos (Athens, 1986), pp. 185-206. Research on Vandal diplomacy also confirms this tendency, see the detailed work by T.C. Lounghis, Les Ambassades Byzantines en Occident depuis la fondation des états barbares jusqu' aux croisades. 407-1096 (Athens, 1980), who also gives the relevant source material, and A. Gillett, Envoys and Political Communication in the Late Antique West $4 I I-533$ (Cambridge, 2003).

${ }^{87}$ J.H. Liebeschuetz, 'Gens into Regnum: The Vandals', in H.W. Goetz, J. Jarnut and W. Pohl (eds), Regna and Gentes: The Relationship between Late Antiquity and Early Medieval Peoples and Kingdoms in the Transformation of the Roman World, The Transformation of the Roman World I3 (Leiden and Boston, 2003), pp. 55-83, here pp. 72-6 and 80-2; G. Maier, Amtsträger und Herrscher der in der Romania-Gothica. Vergleichende Untersuchungen zu den Institutionen der ostgermanischen Völkerwanderungsreiche, Historia Einzelschriften I8I (Stuttgart, 2005); R. Steinacher, 'Gruppen und Identitäten. Gedanken zur Bezeichnung "vandalisch"', in G.M. Berndt and R. Steinacher (eds), Das Reich der Vandalen; R. Heuberger, 'Vandalische Reichskanzlei und Königsurkunden im Vergleich mit verwandten Einrichtungen und Erscheinungen', Mitteilungen des Instituts für Österreichische Geschichtsforschung Ergänzungsband 11 (1929), pp. 89-I24; Courtois, Les Vandales, pp. 248-54. 
system, but both in Italy under Odoacar and Theoderic (in the name of the senate) and at the same time in Vandal North Africa (in the name of the kings), it was refined and improved..$^{88}$

During the 460 s and 470 os the issue of imperial silver coins almost ceased, while the bronze value of smaller coins was reduced. This was owing both to the military and political crises that cost the imperial government a lot of money, and to the inflationary issue of copper coins without measure. The slight decline in the purity of the solidus, which since its introduction and up until the Byzantine Middle Ages remained the guarantor for a stable monetary economy, also played a role. ${ }^{89}$ Odoacar and Theoderic in Italy, as well as the Vandal-Alanic kings, were among the first in the Roman world who were able to reestablish a stable currency of middling and small denominations. The introduction of folles as a multiplicity of nummi values (XL in Italy, XLII in Africa) are noticeable steps in these attempts. The aim of these measures was always to establish a firm relationship between the copper coins and the gold currency. The imperial government in Constantinople quickly followed the Italic and Vandal example with the coinage reforms of Anastasius in $498 .^{\circ}$

\section{Institut zur Interdisziplinären Erforschung des Mittelalters und seines Nachwirkens, Universität Paderborn}

\section{Institut für Mittelalterforschung, Österreichische Akademie der Wissenschaften}

88 A.H.M. Jones, The Later Roman Empire 284-602: A Social, Economic and Administrative Survey I (Oxford, 1964), pp. 443-5.

89 Henning, Periclitans res publica, pp. 26I-7; Jones, Later Roman Empire I, pp. 4II-47.

90 Hendy, Studies in the Byzantine Monetary Economy, pp. 478-90; Morrisson, 'Les origines', pp. 46I-72; K.W. Harl, Coinage in the Roman Economy 300 B.C. to A.D. 700 (Baltimore and London, 1996), pp. I86-95; Liebeschuetz, 'Gens into Regnum', p. 76. The little attention that these problems have received becomes obvious when looking at the Handbuch der europäischen Wirtschafts- und Sozialgeschichte, which does not mention the innovative role of the Vandal kings Theoderic and Odoacre, in the monetary reforms of the second half of the fifth century. See L.Th. Houmanidis, 'Byzanz im Früh-, Hoch- und Spätmittelalter', in J.A. Houtte (ed.), Europäische Wirtschafts- und Sozialgeschichte im Mittelalter (Stuttgart, I980), pp. 47I-504, here p. 488. Although the monetary reform of Anastasius did not fix the relationship between copper and gold, it limited the shifts in value to a controllable degree. See Jones, Later Roman Empire I, pp. 236 and 444. Grierson, 'The Tablettes Albertini and the Value of the Solidus', p. 8o: 'Italy and Africa slowed down and ultimately halted the inflationary movement by issuing larger multiples of nummi in reasonable but not excessive quantities, for these folles and their subdivisions were less easy to counterfeit and their issue could be kept under control.' 


\section{Appendix}

\section{Catalogue of coins from the Vandal period in the Coin Cabinet of Vienna's Kunsthistorisches Museum}

Abbreviations

$\mathrm{AE}$

ANSMN

AR

aes

BMC RE II. Harold Mattingly, Coins of the Roman Empire in the

American Numismatic Society Museum Notes argentum British Museum. Vol. II: Vespasian to Domitian (London, I930).

BMC Vand Warwick Wroth (ed.), Catalogue of the Coins of the Vandals, Ostrogoths and Lombards and of the Empires of Thessalonica, Nicaea and Trebizond in the British Museum (London, I9II; Chicago, i966).

BNP Cécile Morrisson, Catalogue des monnaies byzantines de la Bibliothèque Nationale, Vol. I: D’Anastase Ier a Justinienne II, 49I-7I (Paris, I970).

BSFN Bulletin de la Société Francaise de Numismatique DOC Alfred Bellinger and Ph. Grierson, Dumbarton Oaks Catalogues. Byzantine Coins in the Dumbarton Oaks Collection and the Whittemore Collection, Vol. I: Anastasius I to Maurice 49I-602 (Washington, I966).

MEC Philip Grierson and Mark Blackburn, Medieval European Coinage: With a Catalogue of the Coins in the Fitzwilliam Museum, Cambridge. Vol. I: The Early Middle Ages, $5^{\text {th }}-I 0^{\text {th }}$ Centuries (Cambridge and New York, I986).

MIB I. Vand Wolfgang Hahn, Moneta Imperii Byzantini. Vol I: Von Anastasius I. bis Justinianus I. (49I-565) einschließlich der ostgotischen und vandalischen Prägungen (Vienna, 1973).

MIBE Wolfgang Hahn (and Michael Metlich), Money of the Incipient Byzantine Empire. Anastasius I-Justinian I, 49I-565 (Vienna, 2000).

MÖNG Mitteilungen der Österreichischen Numismatischen Gesellschaft

Mor./Sch. Cécile Morrisson and James H. Schwartz, Coinage in the Name of Honorius, in ANSMN 27 (I982), pp. I4979.

Mor. Cécile Morrisson, 'The Re-Use of Obsolete Coins: The Case of Roman Imperial Bronzes Revived in the Late Fifth Century', in Christopher N.L. Brooke (ed.), 
Studies in Numismatic Method Presented to Philip Grierson (Cambridge, 1983), pp. 95-I08.

NNM American Numismatic Society: Numismatic Notes and Monographs

Obv. Obverse

Pl. Plate

RIC II. Harold Mattingly and Edward Sydenham, The Imperial Roman Coinage. Vol. II: Vespasian to Hadrian (London, I972).

Rev. $\quad$ Reverse

RN Revue Numismatique

W. Inventory number of the Coin Cabinet of the Kunsthistorisches Museum, Vienna 


\section{A. Silver coins in the name of Emperor Honorius}

I

AR Siliqua

$\mathrm{I} .48 \mathrm{~g} ; \mathrm{I} .53 \mathrm{~cm}$

Obv. HONO [ ]

Laureate-headed bust $\mathrm{r}$. wearing cuirass and paludamentum

Rev. ROII $\mathrm{RV}$ [ ]

Roma seated 1. holding Victory on a globe and reversed spear W. I9I.203

cf. MEC I-3; Mor./Sch. 30

2

AR Siliqua

I.80 g; $1.50 \mathrm{~cm}$

Obv. D N HONORI [ ]

Laureate-headed bust $\mathrm{r}$. wearing cuirass and paludamentum

Rev. ROII $\mathrm{RUPS}$

Roma seated 1. holding Victory on a globe and reversed spear W. 19I.204

cf. MEC I-3; Mor./Sch. 30

3

AR Siliqua

I.2I g; I. $33 \mathrm{~cm}$

Obv. HONORIO [ ]

Laureate-headed bust $\mathrm{r}$. wearing cuirass and paludamentum

Rev. [ ] NN [ ]

W. 19I.208

Carthago standing

cf. BMC Vand Pl. I. / I2; MIB I. Vand I

4

AR Siliqua

I.38 g; I. $37 \mathrm{~cm}$

Obv. HONO [ ] PVS AGT

Laureate-headed bust $\mathrm{r}$. wearing cuirass and paludamentum

Rev. A [ ] O IIIII K

Carthago standing with widespread arms, in wreath with star

W. 191.209

cf. BMC Vand Pl. I. / I2; MIB I. Vand I

Early Medieval Europe 2008 I6 (3)

(C) 2008 The Authors. Journal Compilation (C) 2008 Blackwell Publishing Ltd 


\section{B. Royal Vandal coins}

Gunthamund (484-96)

5

AR Siliqua (Ioo denarii)

I. $72 \mathrm{~g} ; 2.00 \mathrm{~cm}$

Obv. DNREXGUN THAMUNDU

Bust r. with diadem, cuirass and paludamentum

Rev. D N under line, in wreath

W. 191.219

cf. MIB I. Vand 2

6

AR Half-Siliqua (50 denarii)

$0.93 \mathrm{~g} ; \mathrm{I} .35 \mathrm{~cm}$

Obv. DNRXG [ ]

Bust $\mathrm{r}$. with diadem, cuirass and paludamentum

Rev. $\quad \mathrm{D} \mathrm{N}$ in wreath with circular ornament

W. 191.220

cf. BMC Vand Pl. II. / 3, 4; MIB I. Vand 3

7

AR Half-Siliqua ( 50 denarii)

$0.94 \mathrm{~g} ; \mathrm{I} .52 \mathrm{~cm}$

Obv. DNRXG [ ] NTHA [ ]

Bust $r$. with diadem, cuirass and paludamentum

Rev. D N in wreath with circular ornament

W. 19I.22I

cf. BMC Vand Pl. II. / 3, 4; MIB I. Vand 3

8

AR Quarter-Siliqua (25 denarii)

$0.44 \mathrm{~g} ; \mathrm{I} .08 \mathrm{~cm}$

Obv. DN [ ]

Bust $\mathrm{r}$. with diadem, cuirass and paludamentum

Rev. D N XXV in wreath

W. 191.222

cf. BMC Vand Pl. II. / 5; MIB I. Vand 4

Thrasamund (496-523)

9

AR Half-Siliqua (5o denarii) 
$0.89 \mathrm{~g} ; \mathrm{I} .32 \mathrm{~cm}$

Obv. DNR [ ] ASAMUDU

Bust r. with diadem, cuirass and paludamentum

Rev. D N in wreath with cross

W. I9I.223

cf. BMC Vand Pl. II. / Iо; MIB I. Vand $5 \mathrm{~b}$

IO

AR Half-Siliqua (5o denarii)

$0.89 \mathrm{~g} ; \mathrm{I} .48 \mathrm{~cm}$

Obv. DNRGTHR [ ] SAMUND [ ]

Bust r. with diadem, cuirass and paludamentum

Rev. D N in wreath with circular ornament

W. 191.224

cf. BMC Vand Pl. II. / II; MIB I. Vand 6b

II

AR Half-Siliqua (5o denarii)

$0.93 \mathrm{~g} ; \mathrm{I} .33 \mathrm{~cm}$

Obv. [] SAMUND [ ]

Bust $r$.

Rev. D N in wreath with circular ornament

W. 191.225

cf. BMC Vand Pl. II. / II; MIB I. Vand 6b

$\mathbf{I 2}$

AE Denarius (2 $1 / 2$ nummi)

$0.50 \mathrm{~g} ; \mathrm{I} .03 \mathrm{~cm}$

Obv. [ ] TASA [ ]

Bust r. with diadem, cuirass and paludamentum

Rev. Victory l. with wreath

W. 191.226

cf. MIB I. Vand I6

13

AE Denarius (2 $1 / 2$ nummi)

$0.87 \mathrm{~g} ; \mathrm{I} .09 \mathrm{~cm}$

Obv. DNRG [ ] ASA

Bust r., with diadem, cuirass and paludamentum

Rev. Victory 1. with wreath

W. I91.227

cf. MIB I. Vand I6

Early Medieval Europe 2008 I6 (3)

(C) 2008 The Authors. Journal Compilation (C) 2008 Blackwell Publishing Ltd 
I4

AE Denarius (2 $1 / 2$ nummi)

$0.58 \mathrm{~g} ; 0.98 \mathrm{~cm}$

Obv. DNR [ ] SA

Bust $\mathrm{r}$. with diadem, cuirass and paludamentum

Rev. Victory l. with wreath

W. I9I.23I

cf. MEC Pl. I. / 19, 20; MIB I. Vand I6

Hilderic (523-30)

I5

AR Half-Siliqua (50 denarii)

I.23 g; I. $50 \mathrm{~cm}$

Obv. DNHILDI RIXREX

Bust $r$. with diadem, cuirass and paludamentum

Rev. FELIX KARTG

Carthago standing, frontal

W. 191.228

cf. MIB I. Vand 8; MEC 2I

16

AE Denarius ( $21 / 2$ nummi) of Hilderic (523-30)

$0.52 \mathrm{~g}$; 0.9I cm

Obv. [ ] IR I [ ]

Bust $r$.

Rev. Cross on globe, in wreath

W. 191.272

cf. BMC Vand Pl. II. / I8; MEC 24, 25; MIB I. Vand 2I

17

AE Denarius ( $21 / 2$ nummi) of Hilderic $(523-50)$

$0.47 \mathrm{~g} ; 0.93 \mathrm{~cm}$

Obv. Bust r.

Rev. Cross on globe, in wreath

W. 191.273

cf. BMC Vand Pl. II. / I8; MEC 24, 25; MIB I. Vand 2I

18

AE Denarius ( $21 / 2$ nummi) of Hilderic $(523-30)$

$0.4 \mathrm{I} \mathrm{g} ; 0.94 \mathrm{~cm}$

Obv. illegible

Rev. Cross on globe, in wreath 
W. 191.274

cf. BMC Vand Pl. II. / I8; MEC 24, 25; MIB I. Vand 2I

Gelimer (530-4)

I9

AR Half-Siliqua (5o denarii)

I.I2 g; I.5O cm

Obv. [ ] N [ ] EILAMIR

\section{Bust $\mathrm{r}$.}

Rev. $\mathrm{D} \mathrm{N}$ in wreath with cross

W. 191.229

cf. BMC Vand Pl. II. / I9MIB I. Vand I2;

20

AE Denarius (2 $1 / 2$ nummi)

$0.75 \mathrm{~g} ; 0.85 \mathrm{~cm}$

Obv. illegible

Rev. Monogram in wreath

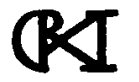

W. 191.230

cf. BMC Vand Pl. II. / 20, 2I; MEC 28, 29; MIB I. Vand 25

2I

$\mathrm{AE} 4$ nummi (?)

I.29 g; $1.07 \mathrm{~cm}$

Obv. DNR [ ] A

Bust $r$.

Rev. VICTO [ ]

Victory with wreath

W. I9I.232

cf. MEC Pl. II. / 31, 32

22

AE Denarius (2 $1 / 2$ nummi)

$0.34 \mathrm{~g} ; 0.9 \mathrm{I} \mathrm{cm}$

Obv. Bust r.

Rev. Victory with sceptre

W. I9I.233

cf. MEC Pl. I. / I9, 20; MIB I. Vand I6

(C) 2008 The Authors. Journal Compilation (C) 2008 Blackwell Publishing Ltd 
23

AE Imitative Issue

I.28 g; $1.07 \mathrm{~cm}$

Obv. Bust r.

Rev. Victory

Denoted transcript

W. I9I.234

cf. BMC Vand Pl. III. / Io

\section{Coins from Vandal North Africa not attributable to a specific king}

24

AE 42 nummi

I0.30 g; $2.77 \mathrm{~cm}$

Obv. KART HAGO

Soldier standing

Rev. XLII

Horse's head 1. above mark of value

W. I9I.205

cf. BMC Vand Pl. I. / 7, 8; MEC 43, 44; MIB I. Vand 22

25

AE 2I nummi

$8.70 \mathrm{~g} ; 2.28 \mathrm{~cm}$

Obv. KART [ ]

Soldier standing

Rev. XXI

Horse's head 1. above mark of value

W. I91.206

cf. BMC Vand Pl. I. / 9, IO; MEC 45-47; MIB I. Vand 23

26

AE 2I nummi

$9.32 \mathrm{~g} ; 2.20 \mathrm{~cm}$

Obv. KART HAGO

Rev. XXI

Soldier standing

Horse's head 1. above mark of value

W. I9I.207

cf. BMC Vand Pl. I. / 9, IO; MEC 45-47; MIB I. Vand 23 
27

AE 42 nummi

$9.28 \mathrm{~g} ; 2.72 \mathrm{~cm}$

Obv. Carthago standing in wreath

Rev. N XLII in wreath

W. I91.210

cf. BMC Vand Pl. I. / I3, I4; MIB I. Vand I7a, I7b

28

AE 42 nummi

$9.86 \mathrm{~g} ; 2.66 \mathrm{~cm}$

Obv. Carthago standing in wreath

Rev. N XLII in wreath

W. I9I.2II

cf. BMC Vand Pl. I. / I3, I4; MIB I. Vand I7a, I7b

\section{9}

AE 42 nummi

II. $22 \mathrm{~g} ; 2.54 \mathrm{~cm}$

Obv. Carthago standing in wreath

Rev. N XLII in wreath

W. 191.2I2

cf. BMC Vand Pl. I. / I3, I4; MIB I. Vand I7a, I7b

30

AE 2I nummi

$7.62 \mathrm{~g} ; 2.18 \mathrm{~cm}$

Obv. Carthago standing

Rev. N XXI in wreath

W. 191.213

cf. BMC Vand Pl. I. / I5; MIB I. Vand I8

3I

AE I2 nummi

$4.17 \mathrm{~g} ; 2.18 \mathrm{~cm}$

Obv. Carthago standing

Rev. N XII in wreath

W. I9I.2I4 (no picture)

cf. BMC Vand Pl. I. / I6; MIB I. Vand I9

32

AE I2 nummi

$4.62 \mathrm{~g} ; 2.00 \mathrm{~cm}$

Early Medieval Europe 2008 I6 (3)

(C) 2008 The Authors. Journal Compilation (C) 2008 Blackwell Publishing Ltd 
Obv. Carthago standing in wreath

Rev. N XII in wreath

W. I9I.215

cf. BMC Vand Pl. I. / I6; MIB I. Vand I9

33

AE 4 nummi

I.3O g; I.I2 cm

Obv. Bust l., palm leaf

Rev. N IIII in wreath

W. 191.216

cf. BMC Vand Pl. I. / I7; MIB I. Vand 20

34

AE 4 nummi

I.05 g; $1.17 \mathrm{~cm}$

Obv. Bust 1., palm leaf

Rev. N IIII in wreath

W. I9I.2I7

cf. BMC Vand Pl. I. / I7; MIB I. Vand 20

\section{Countermarked early imperial bronze coins}

35

AE Dupondius of Domitian (8I-96)

$9.28 \mathrm{~g} ; 2.58 \mathrm{~cm}$

Obv. [ ] DOMITIAN COS II [ ]

Bust 1 .

Rev. Countermark XLII

Standing female with lance (Minerva?)

W. I9I.2I8

cf. BMC RE II. Pl. XXVII / 9, Io

36

AE As of Vespasian (69-79)

IO. $83 \mathrm{~g} ; 2.76 \mathrm{~cm}$

Obv. CAESVESPAUGPMTPCOSIIICAES

Bust $r$.

Countermark (?)

Rev. VICTORIA AUGUST S C

Victory advancing $r$.

W. 191.397

cf. BMC RE II. Pl. XXVI. / Io; RIC II. 549 


\section{7}

AE As of Vespasian (Rome, 73)

I0.92 g; $2.89 \mathrm{~cm}$

Obv. IMPCAESVESPAUGPMTPCOSIIIICAES

Bust r.

Countermark XLII

Rev. VICTORIA AUGUST S C

Victory advancing $r$.

W. I9I.398

cf. like BMC RE II. 665, Pl. XXVI. / Io; RIC II. 549 (CAES instead of CENS)

38

AE $A s$ of Titus for Vespasian (Rome, 73)

I0.62 g; $2.64 \mathrm{~cm}$

Obv. CAESIMPPONTI [ ] PCOS.II [ ]

Bust $r$.

Countermark XLII

Rev. IUDEA [ ] APT [ ] S C

W. I9I.53I

cf. RIC II. 653

\section{9}

AE Dupondius of Vespasian (69-79)

$9.64 \mathrm{~g} ; 2.76 \mathrm{~cm}$

Obv. [ ] RVESPASIA [ ]

Bust $r$.

Countermark XLII

Rev. [] TORIA AUGUST S C

Victory advancing $r$.

W. I9I.532

40

AE $A s$ of Domitian (Rome, 8I-96)

$8.92 \mathrm{~g} ; 2.74 \mathrm{~cm}$

Obv. CAESARAUGDOMITI [ ]

Bust $r$.

Countermark XLII (inverted)

Rev. Temple

Countermark XLII

W. I9I.533

cf. BMC RE II. 69I, Pl. XXVIII. / 3; RIC II. 705

Early Medieval Europe 200816 (3)

(C) 2008 The Authors. Journal Compilation (C) 2008 Blackwell Publishing Ltd 
4I

AE As of Titus for Vespasian (Rome, 72 or $77 / 78$ )

I0.08 g; $2.67 \mathrm{~cm}$

Obv. TCAESARVESPASIANUST [ ] COS [ ]

Bust 1.

Countermark XLII

Rev. S C

Standing figure (Spes)

W. 19I.584

cf. BMC RE II. 74I; RIC II. 622 or 684

42

AE As of Domitian (Rome, 8I-96)

I3.74 g; $2.85 \mathrm{~cm}$

Obv. CAESARAUGFDOMITIANCOS [ ]

Bust $r$.

Countermark XLII

Rev. FELICITAS PUBLICA S C

Standing female

W. 194.856

cf. RIC II. 695

43

AE Dupondius of Galba (Rome, 68)

I3.16 g; $2.90 \mathrm{~cm}$

Obv. IMPSERGALBA [ ] AU [ ]

Bust $r$.

Countermark XLII

Rev. PAX AUGUST S C

Standing female

W. 194.857

cf. RIC II. 64

44

$\mathrm{AE}$ As of Vespasian (Rome, 72/73)

I5.0 g; $2.9 \mathrm{I} \mathrm{cm}$

Obv. IMPCAESVESPASIANAUGCOSIII

Bust $r$.

Countermark XLII (inverted)

Rev. IUDEA CAPTA S C

Seated figure, leaning on a tree

W. 198.326

cf. BMC RE II, 604, Pl. XXIII. / ıо; RIC II. 489; Mor. I, 2 


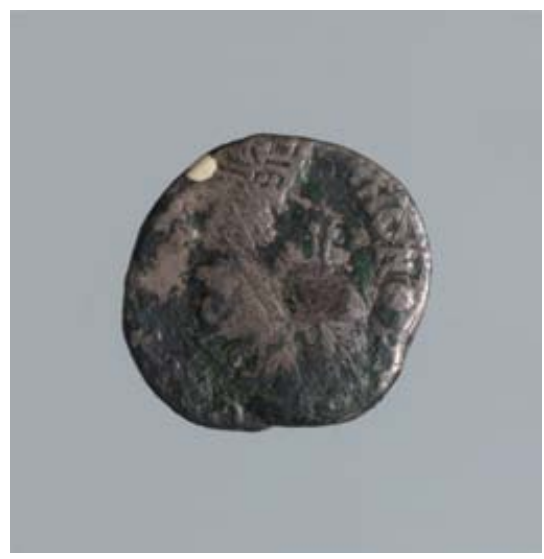

No. 1 - Obv.

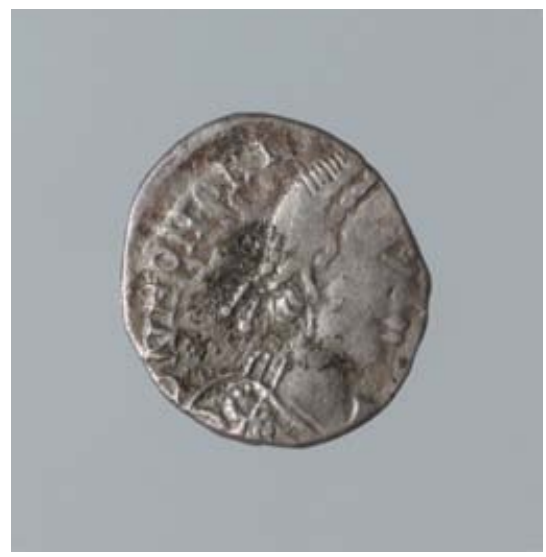

No. 2 - Obv.

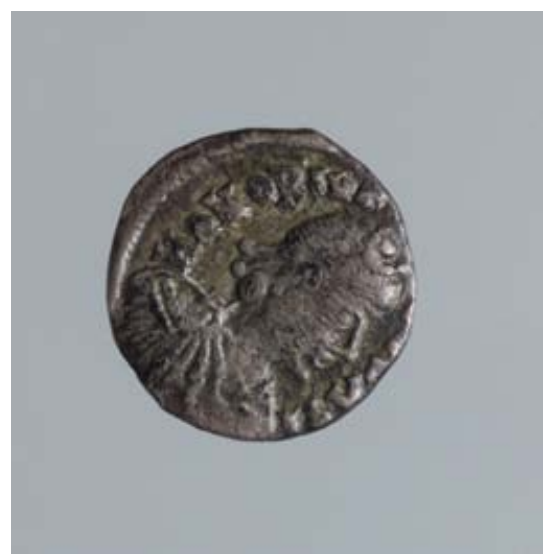

No. 3 - Obv.

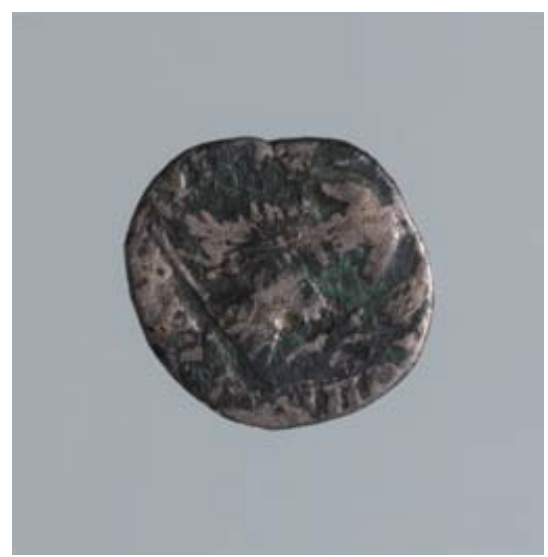

No. 1 - Rev.

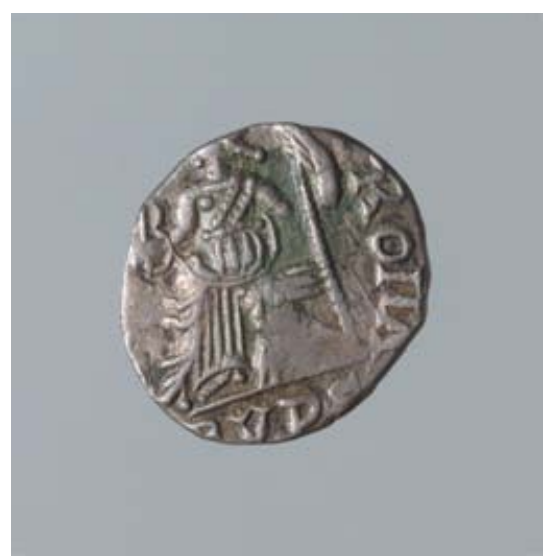

No. 2 - Rev.

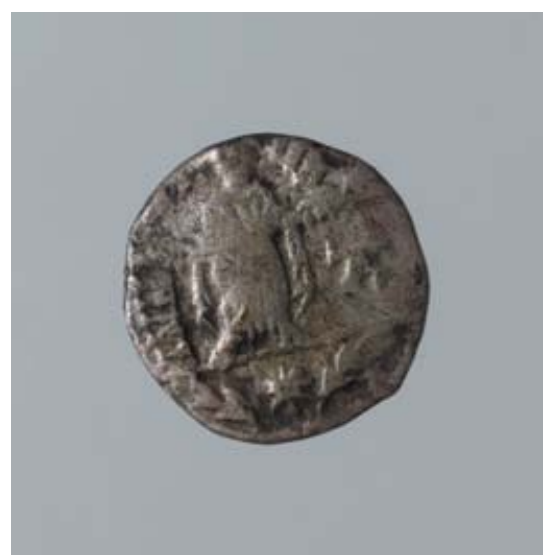

No. 3 - Rev.

Early Medieval Europe 2008 I6 (3)

(C) 2008 The Authors. Journal Compilation (C) 2008 Blackwell Publishing Ltd 


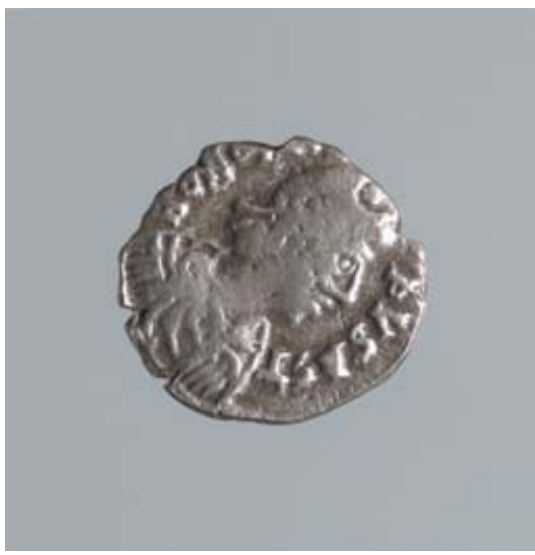

No. 4 - Obv.

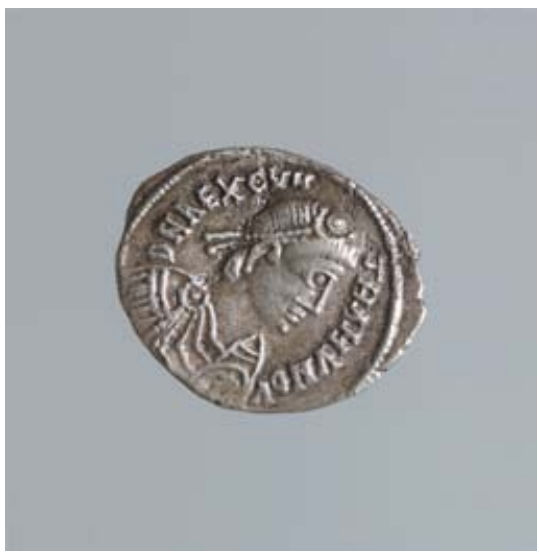

No. 5 - Obv.

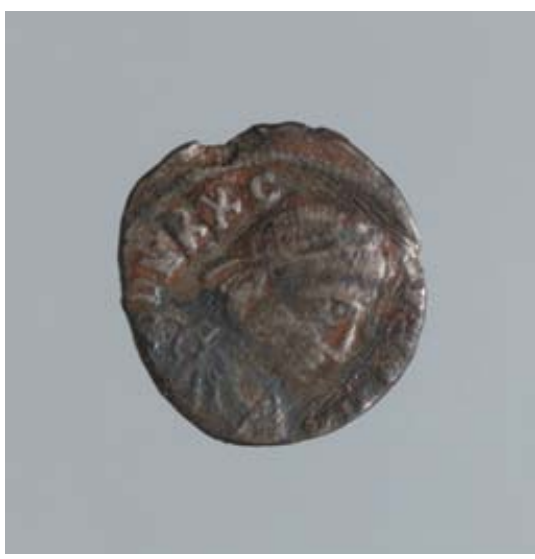

No. 6 - Obv.

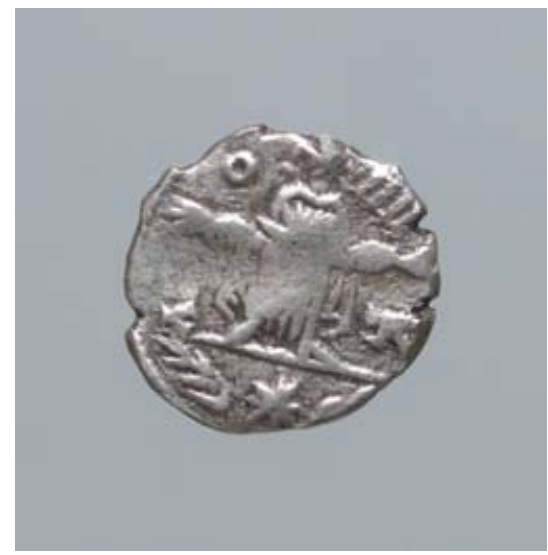

No. 4 - Rev.

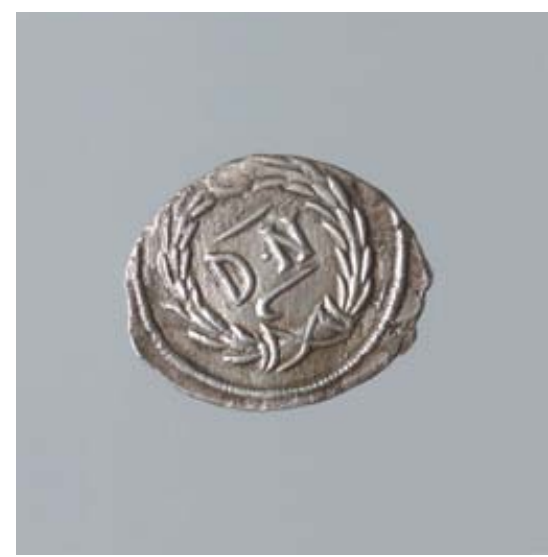

No. 5 - Rev.

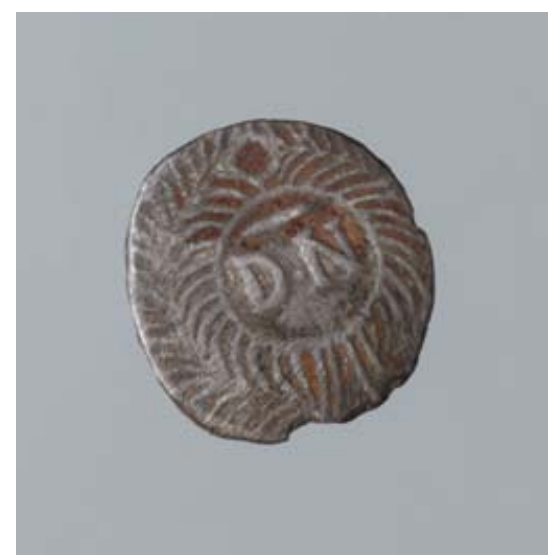

No. 6 - Rev.

Early Medieval Europe 2008 I6 (3) (C) 2008 The Authors. Journal Compilation (C) 2008 Blackwell Publishing Ltd 


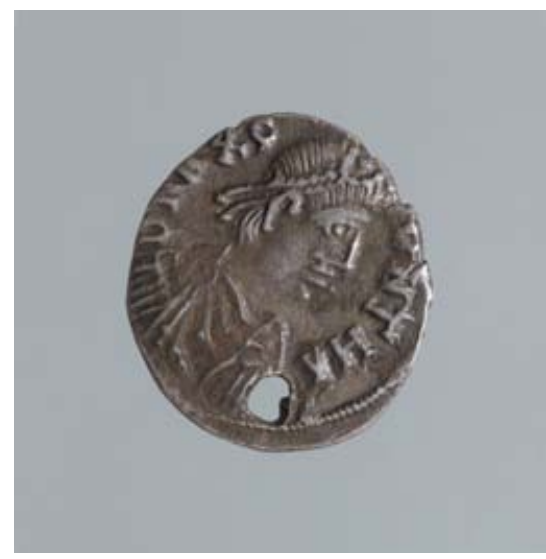

No. 7 - Obv.

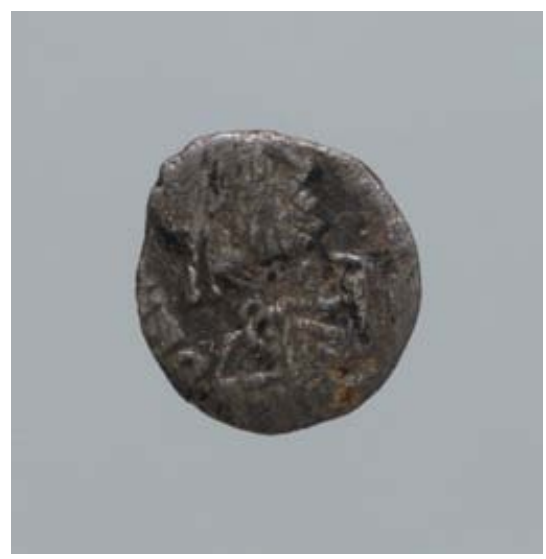

No. 8 - Obv.

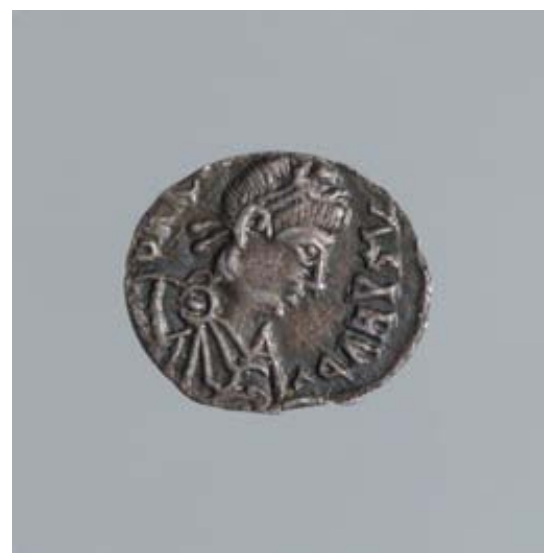

No. 9 - Obv.

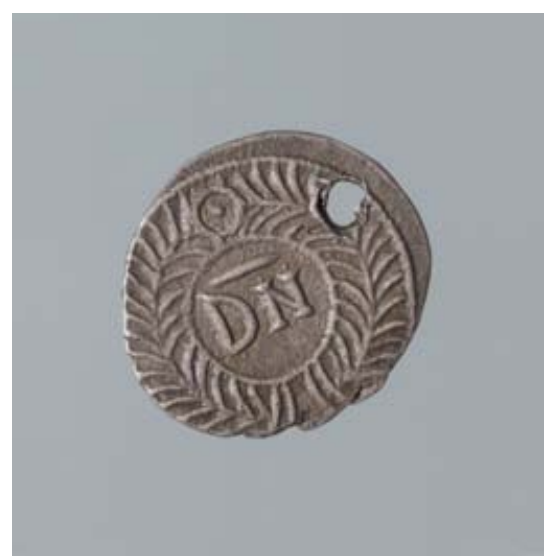

No. 7 - Rev.

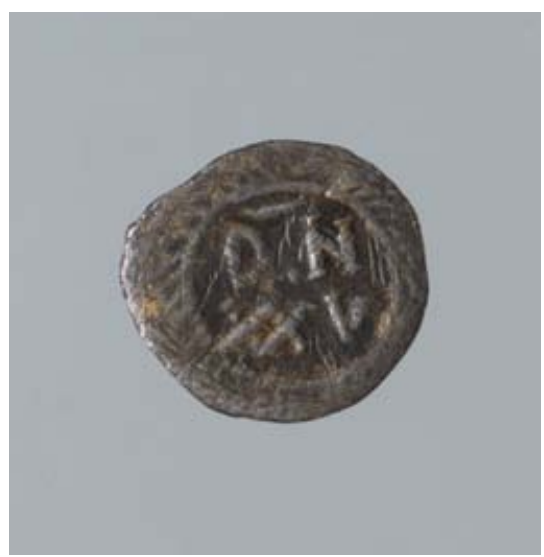

No. 8 - Rev.

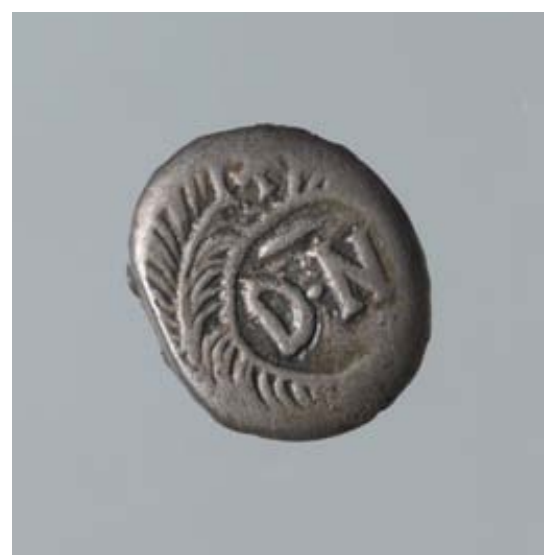

No. 9 - Rev.

Early Medieval Europe 2008 I6 (3)

(C) 2008 The Authors. Journal Compilation (C) 2008 Blackwell Publishing Ltd 


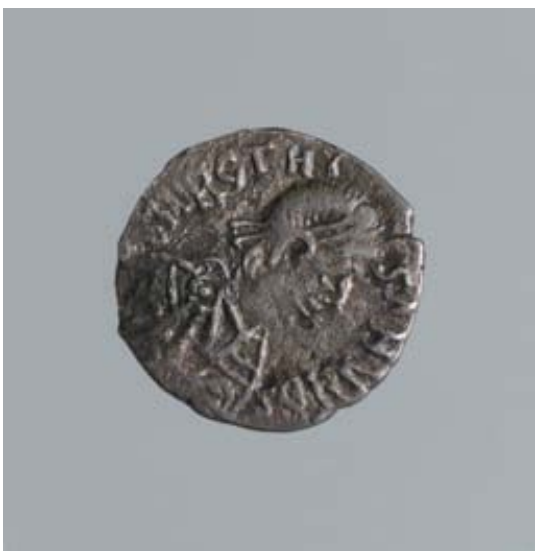

No. 10 - Obv.

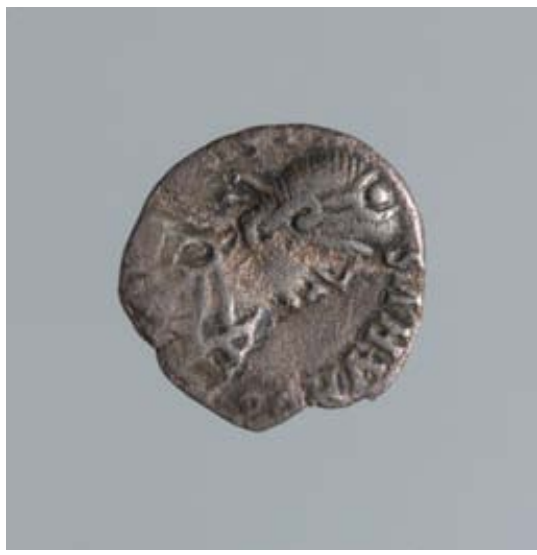

No. 11 - Obv.

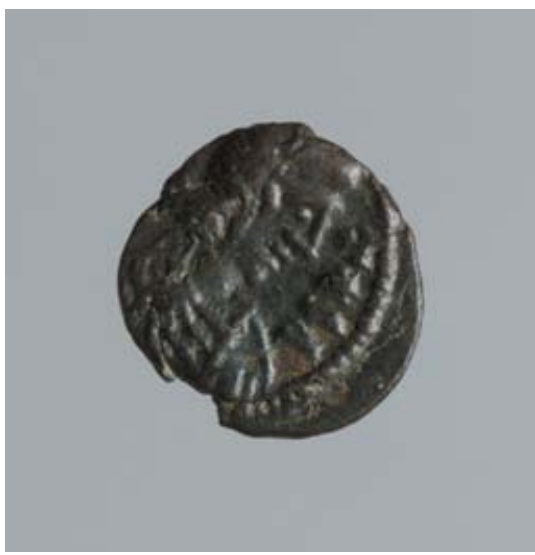

No. 12 - Obv.

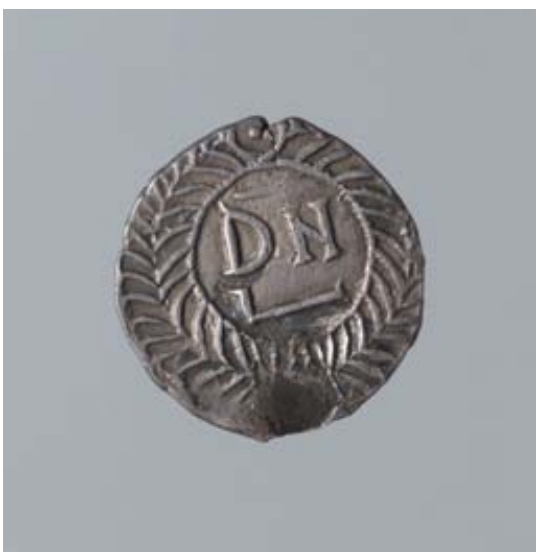

No. 10 - Rev.

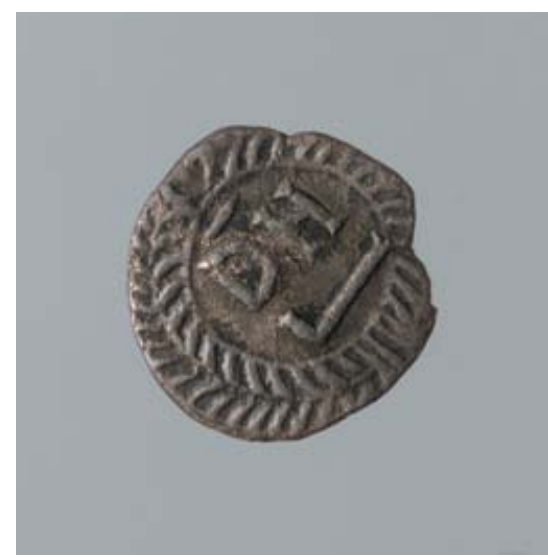

No. $11-$ Rev.

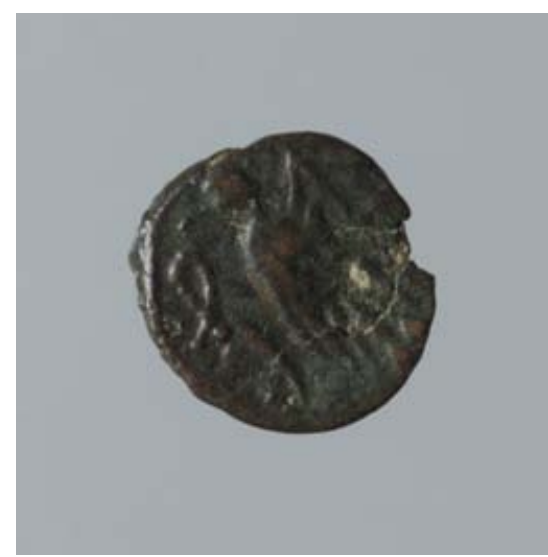

No. 12 - Rev.

Early Medieval Europe 2008 I6 (3) (C) 2008 The Authors. Journal Compilation (C) 2008 Blackwell Publishing Ltd 


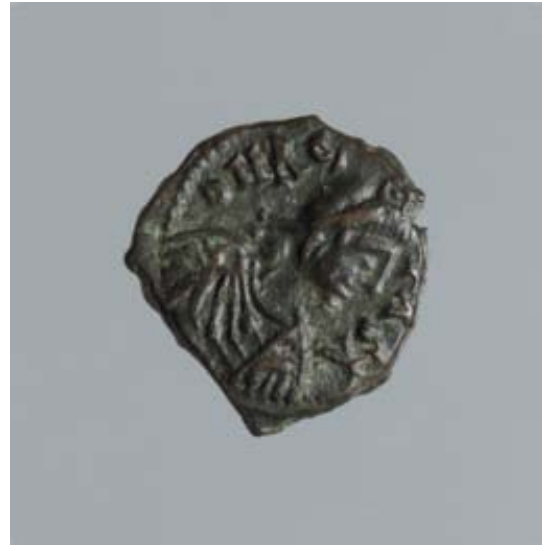

No. 13 - Obv.

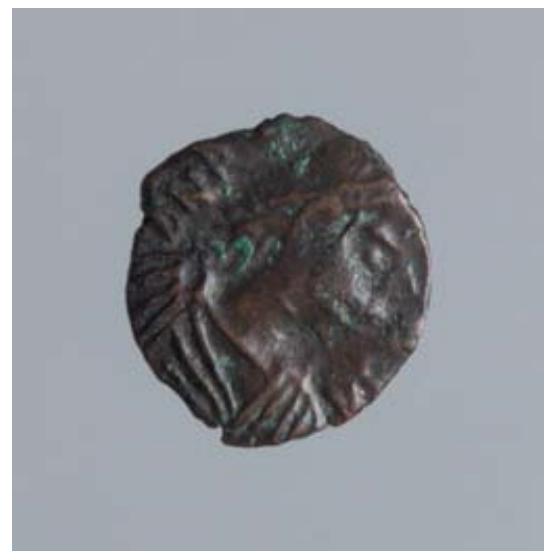

No. 14 - Obv.

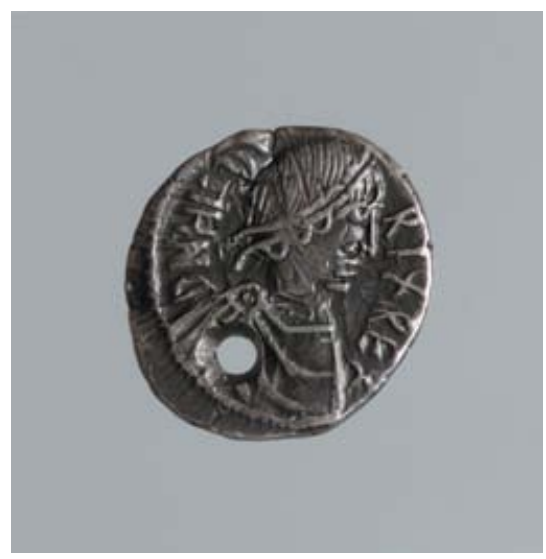

No. 15 - Obv.

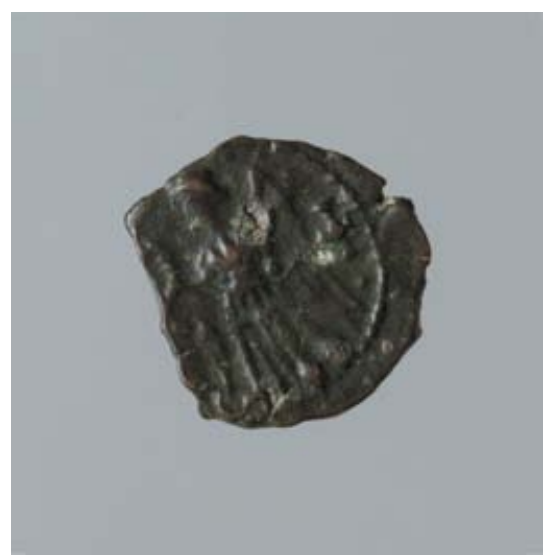

No. 13 - Rev.

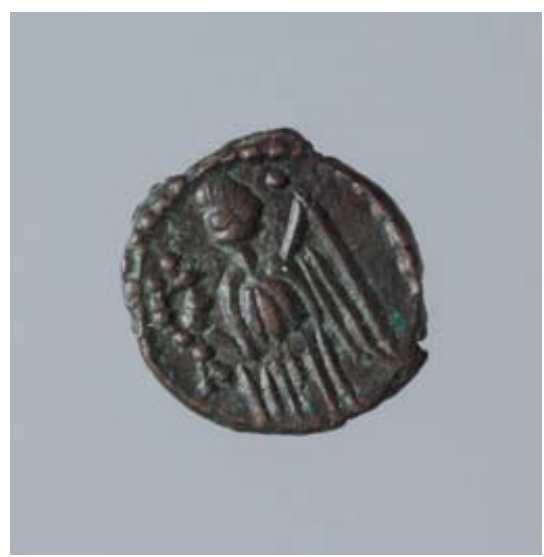

No. 14 - Rev.

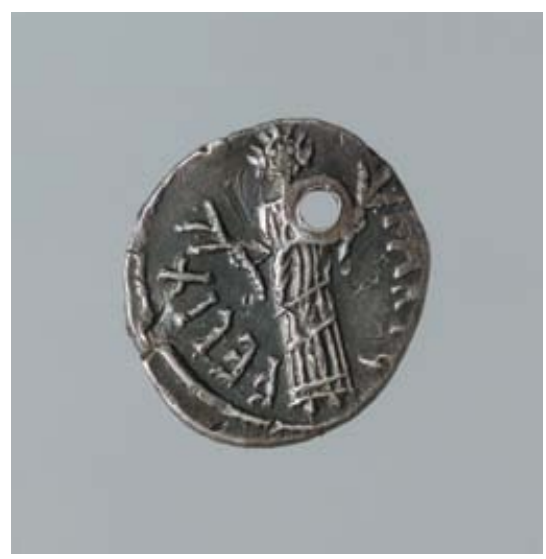

No. 15 - Rev.

Early Medieval Europe 2008 I6 (3)

(C) 2008 The Authors. Journal Compilation (C) 2008 Blackwell Publishing Ltd 


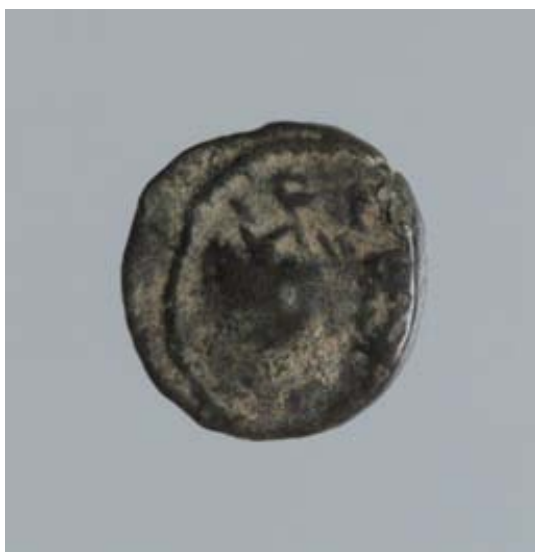

No. $16-$ Obv.

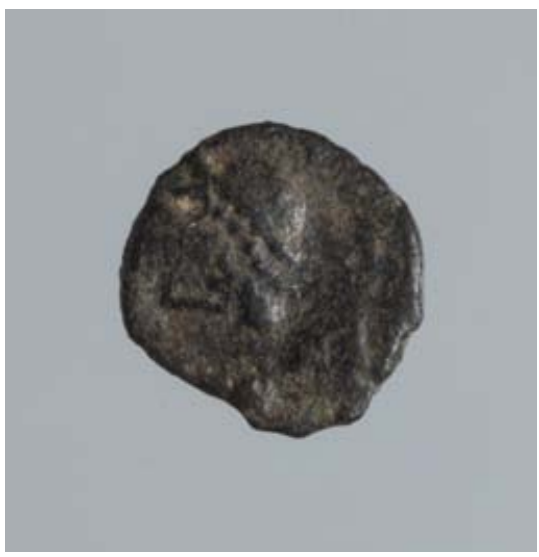

No. 17 - Obv.

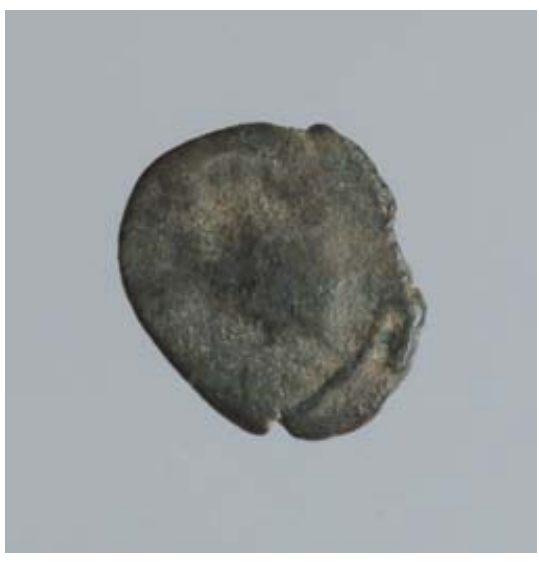

No. 18 - Obv.

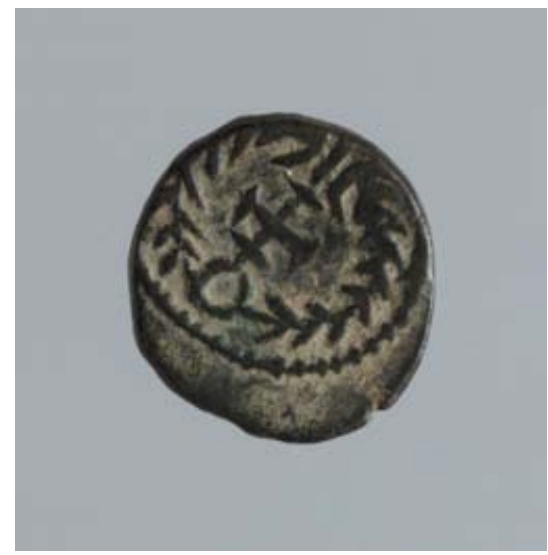

No. 16 - Rev.

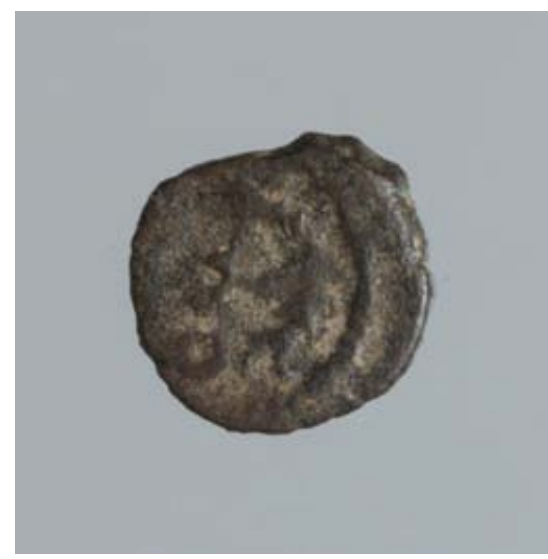

No. 17 - Rev.

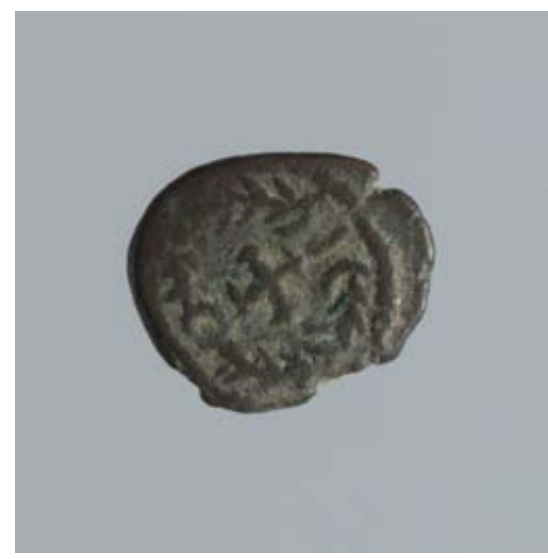

No. 18 - Rev.

Early Medieval Europe 2008 I6 (3) (C) 2008 The Authors. Journal Compilation (C) 2008 Blackwell Publishing Ltd 


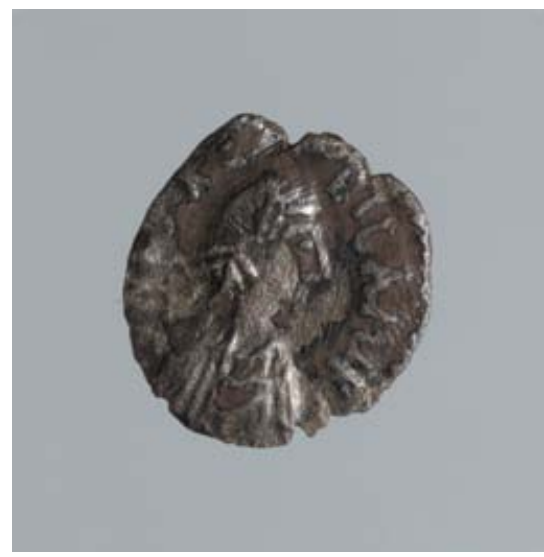

No. 19 - Obv.

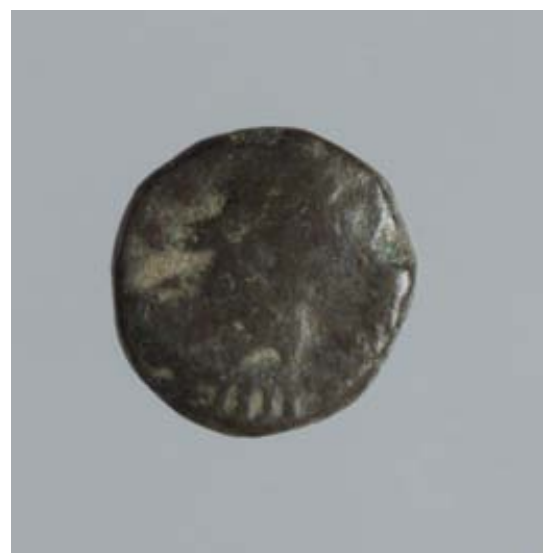

No. 20 - Obv.

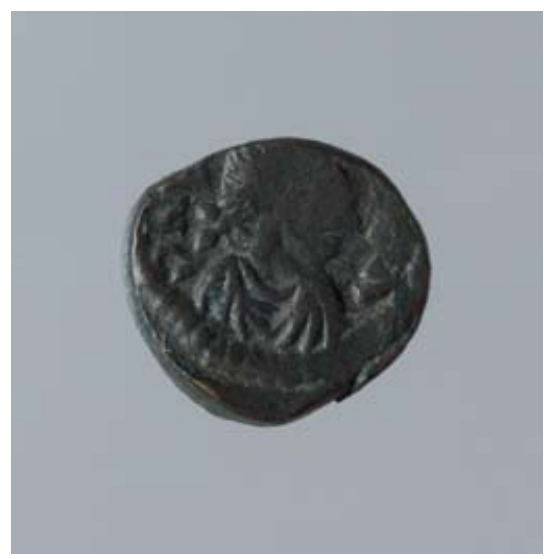

No. 21 - Obv.

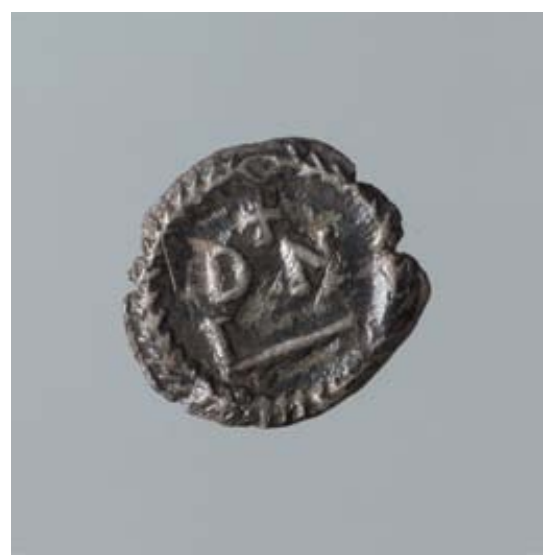

No. 19 - Rev.

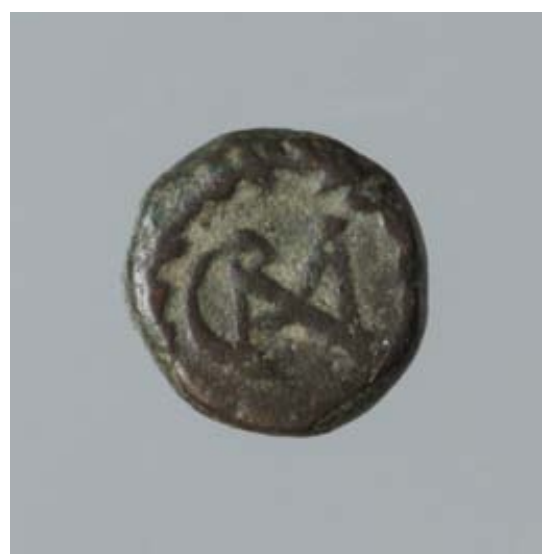

No. 20 - Rev.

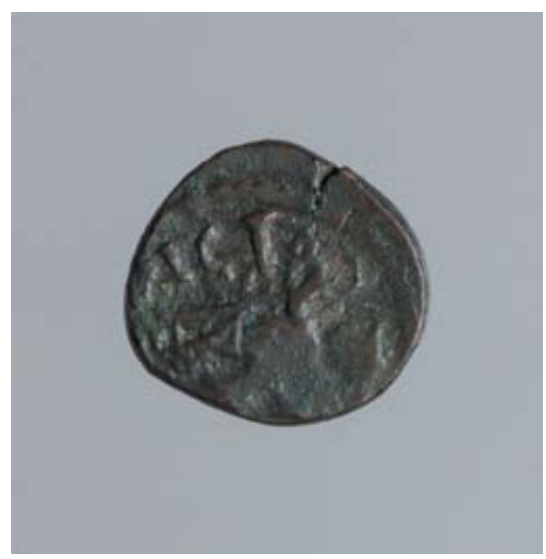

No. 21 - Rev.

Early Medieval Europe 2008 I6 (3)

(C) 2008 The Authors. Journal Compilation (C) 2008 Blackwell Publishing Ltd 


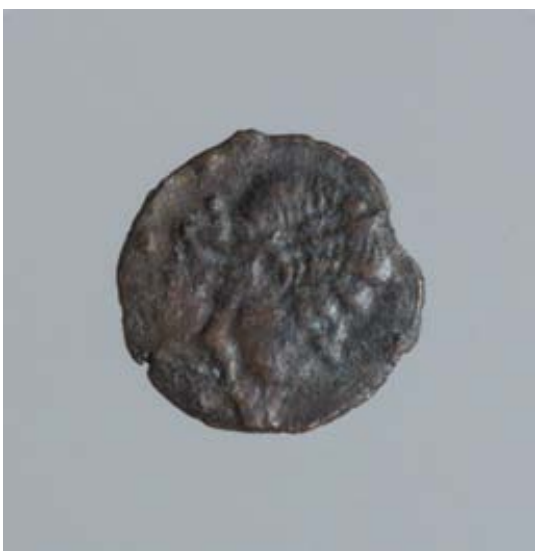

No. 22 - Obv.

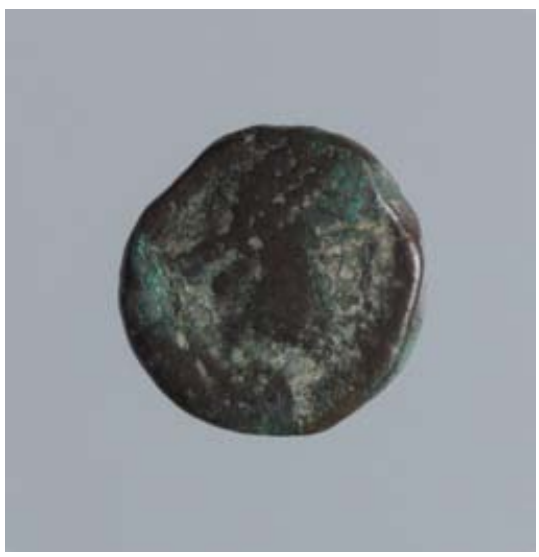

No. 23 - Obv.

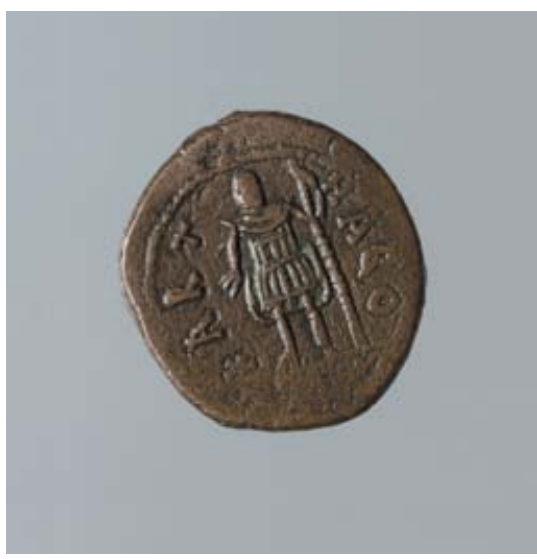

No. 24 - Obv.

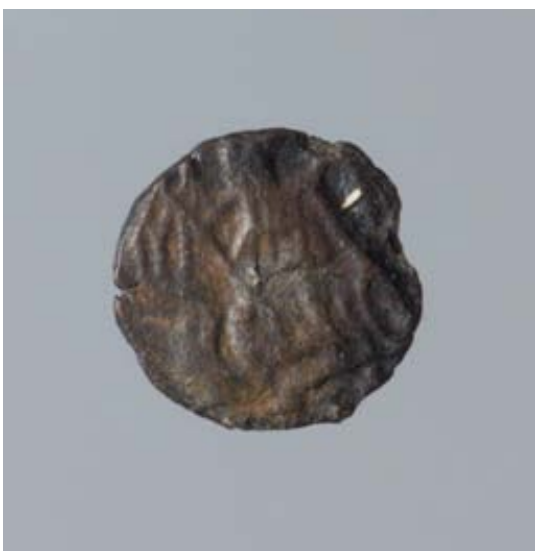

No. 22 - Rev.

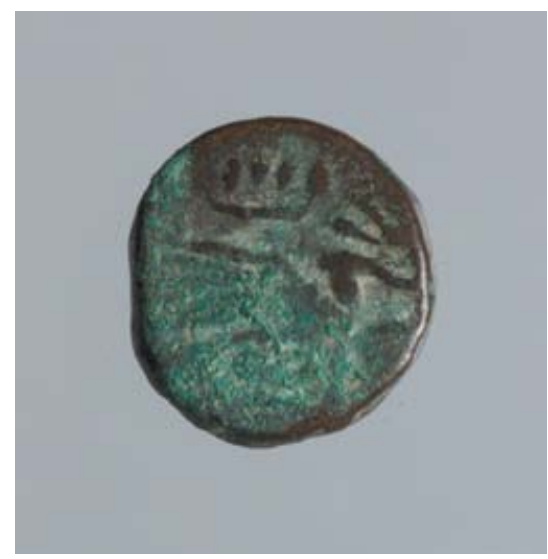

No. 23 - Rev.

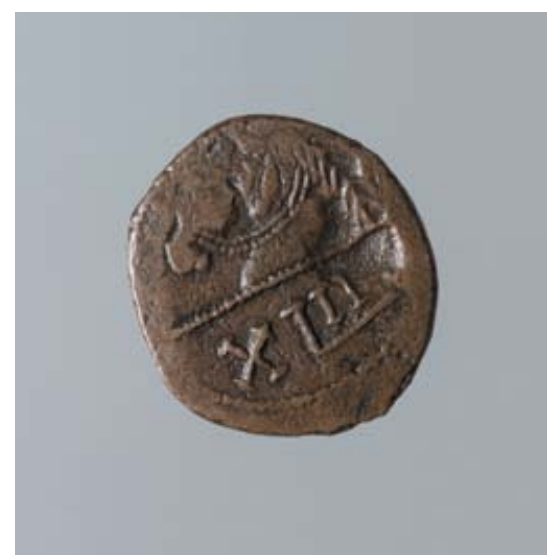

No. $24-$ Rev.

Early Medieval Europe 2008 I6 (3) (C) 2008 The Authors. Journal Compilation (C) 2008 Blackwell Publishing Ltd 


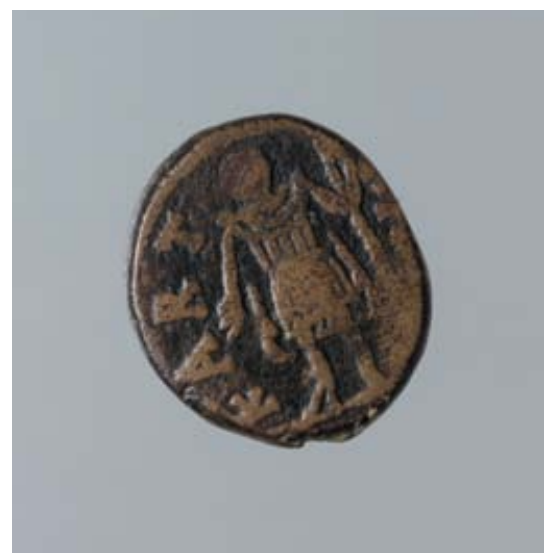

No. 25 - Obv.

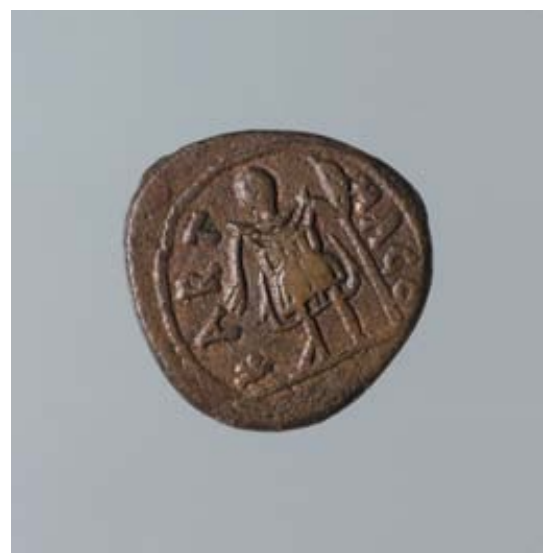

No. 26 - Obv.

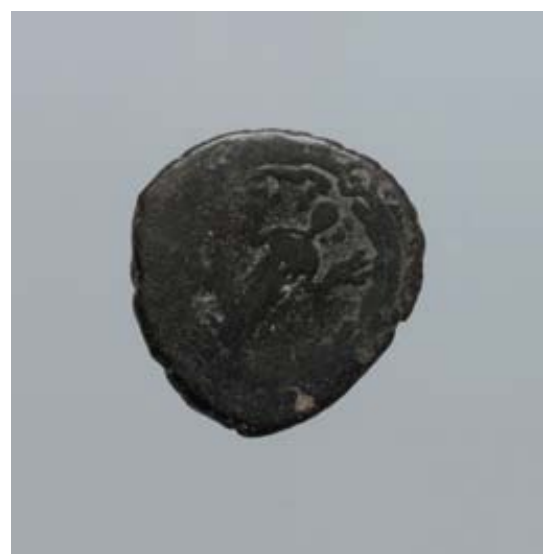

No. 27 - Obv.

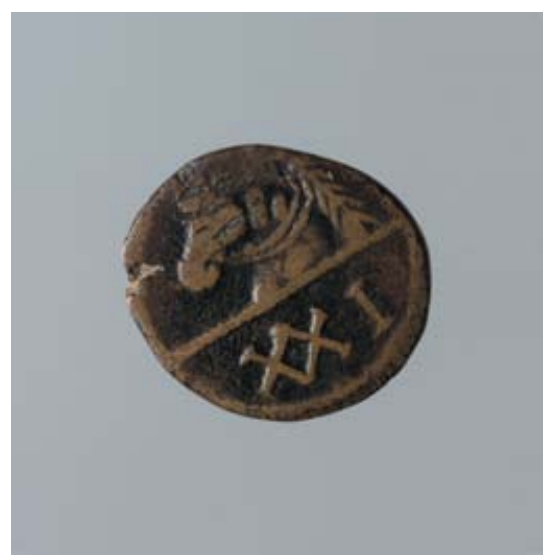

No. 25 - Rev.

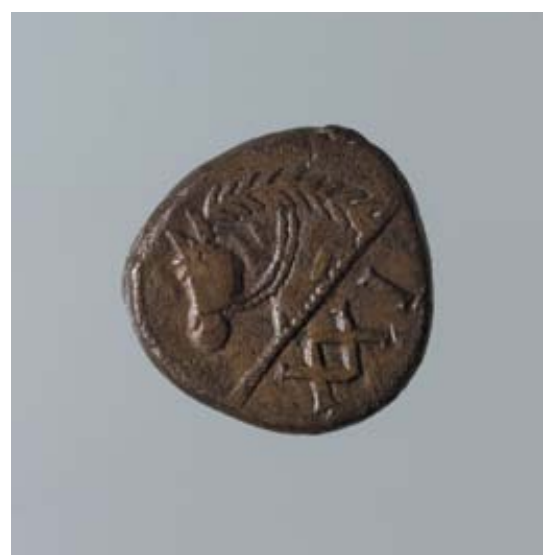

No. 26 - Rev.

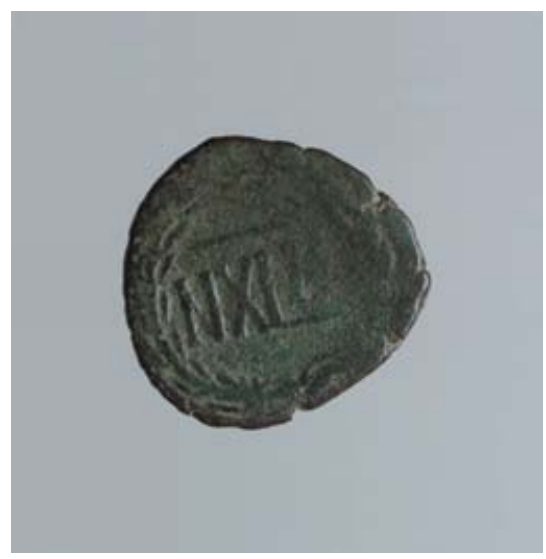

No. 27 - Rev.

Early Medieval Europe 2008 I6 (3)

(C) 2008 The Authors. Journal Compilation (C) 2008 Blackwell Publishing Ltd 


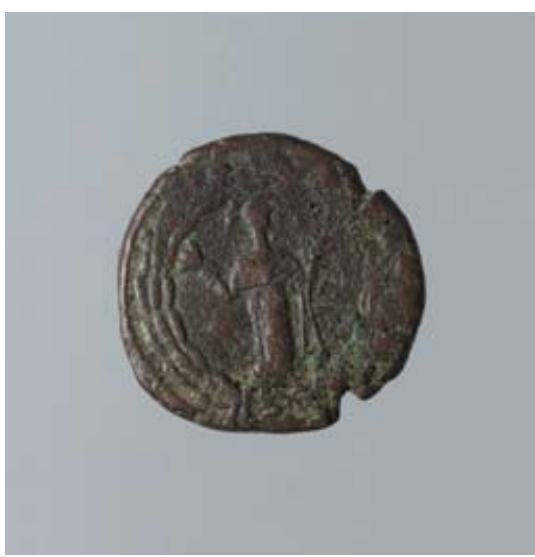

No. 28 - Obv.

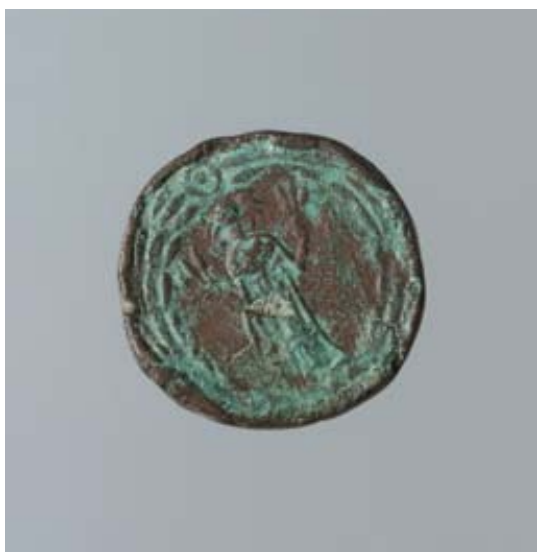

No. 29 - Obv.

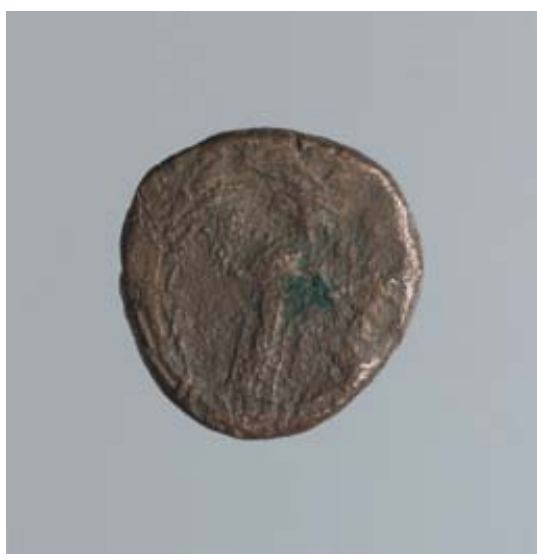

No. 30 - Obv.

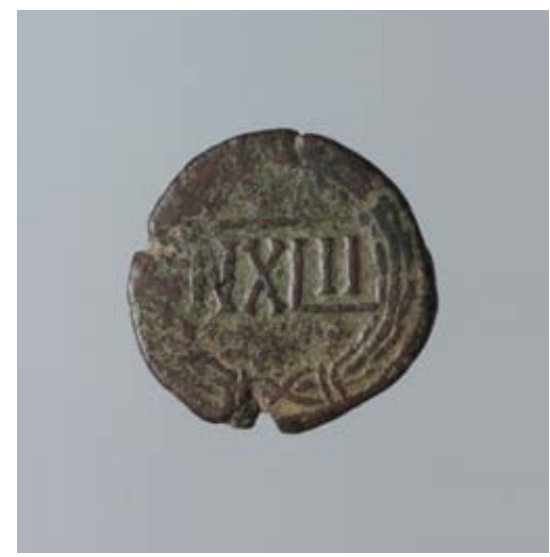

No. 28 - Rev.

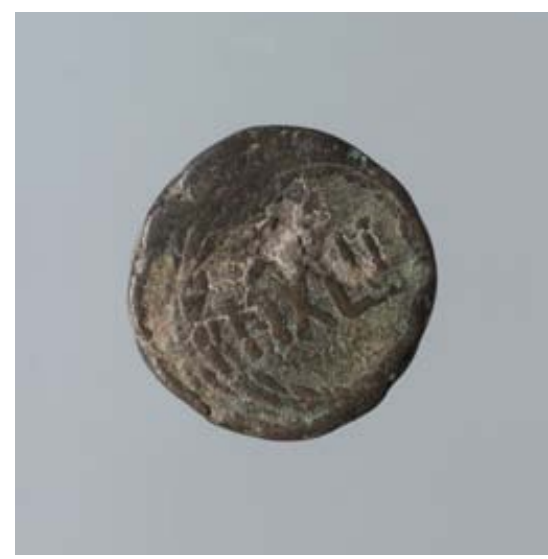

No. 29 - Rev.

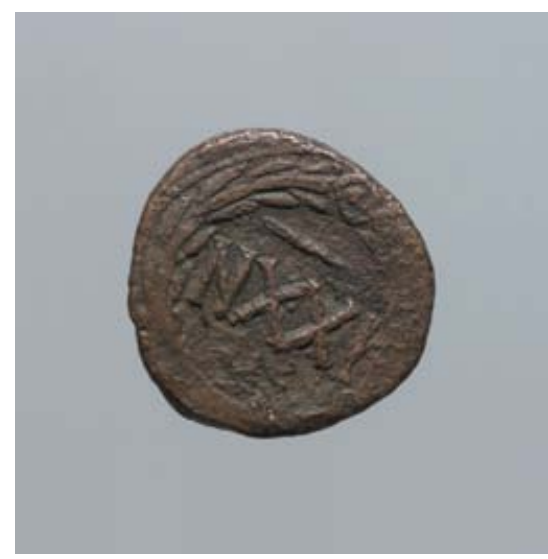

No. 30 - Rev.

Early Medieval Europe 2008 I6 (3) (C) 2008 The Authors. Journal Compilation (C) 2008 Blackwell Publishing Ltd 


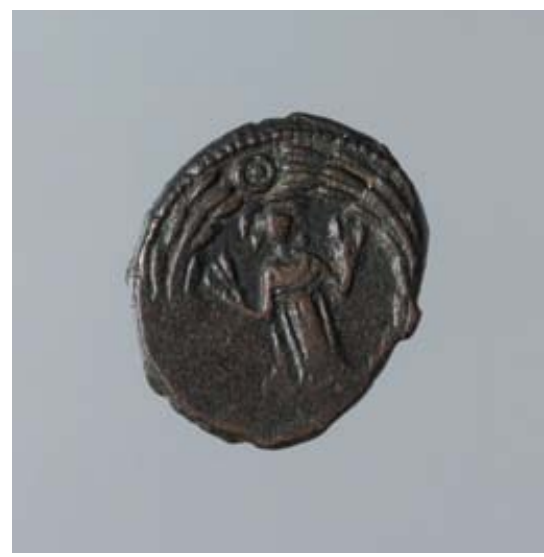

No. 32 - Obv.

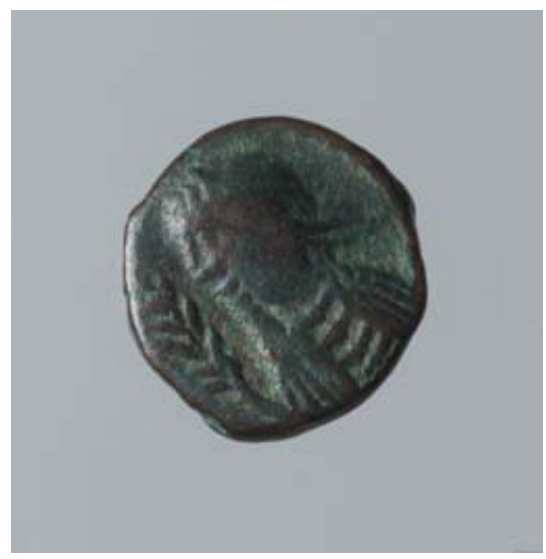

No. 33 - Obv.

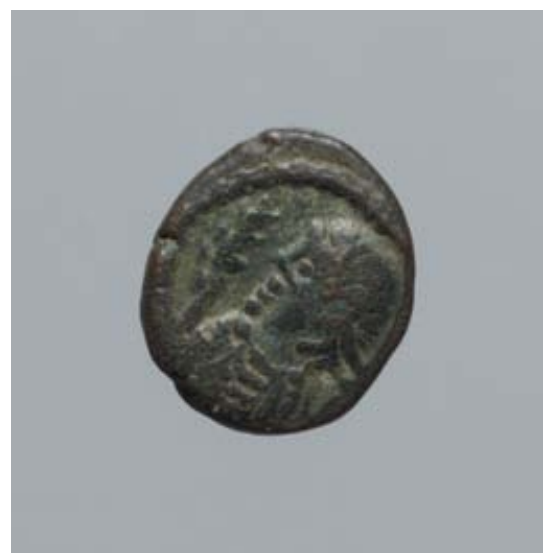

No. 34 - Obv.

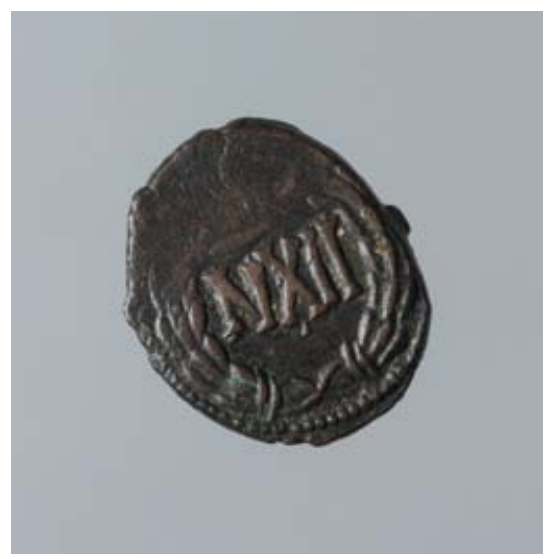

No. 32 - Rev.

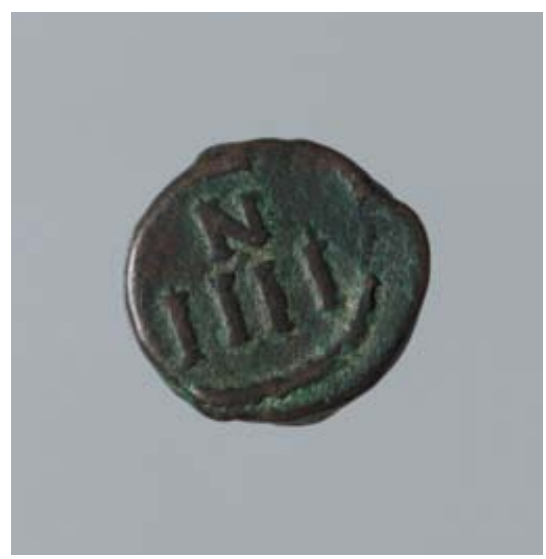

No. 33 - Rev.

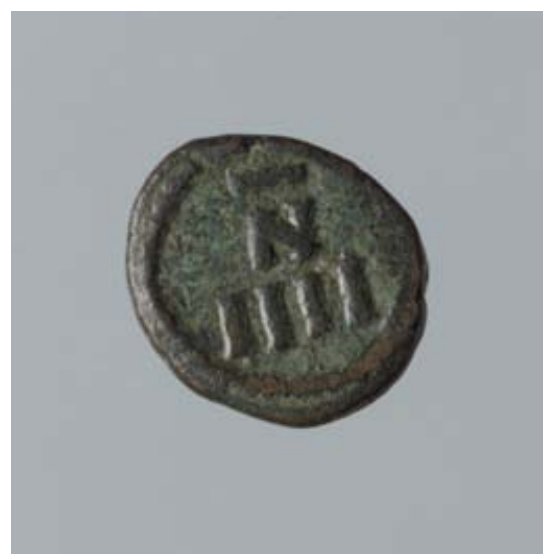

No. 34 - Rev.

Early Medieval Europe 2008 I6 (3)

(C) 2008 The Authors. Journal Compilation (C) 2008 Blackwell Publishing Ltd 


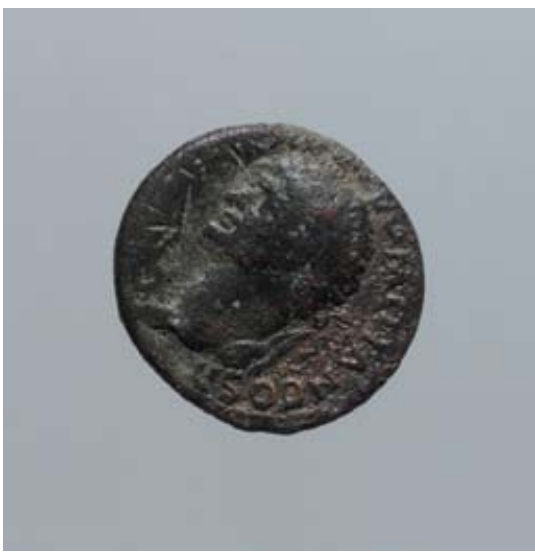

No. 35 - Obv.

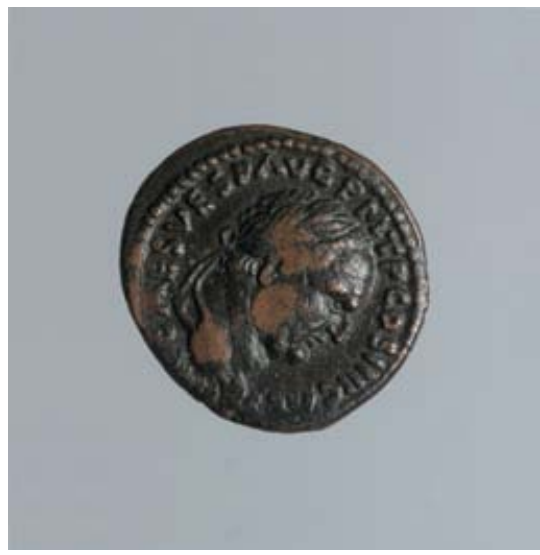

No. 36 - Obv.

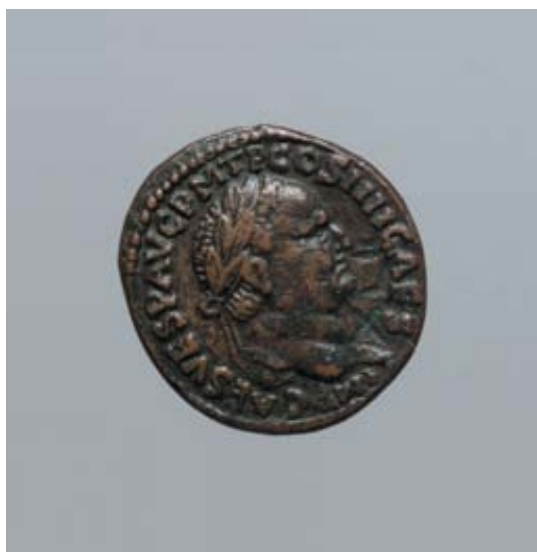

No. 37 - Obv.

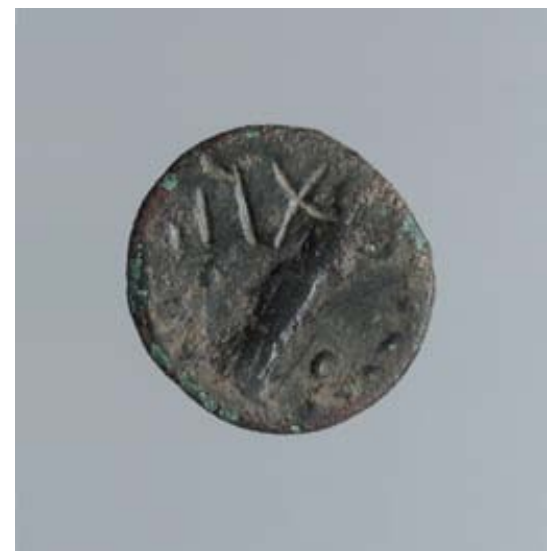

No. 35 - Rev.

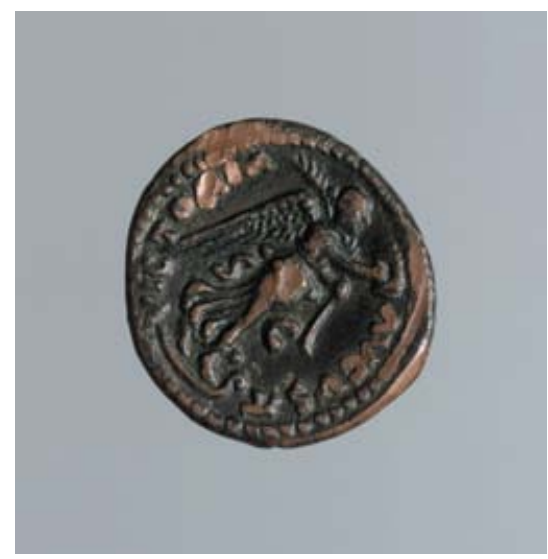

No. 36 - Rev.

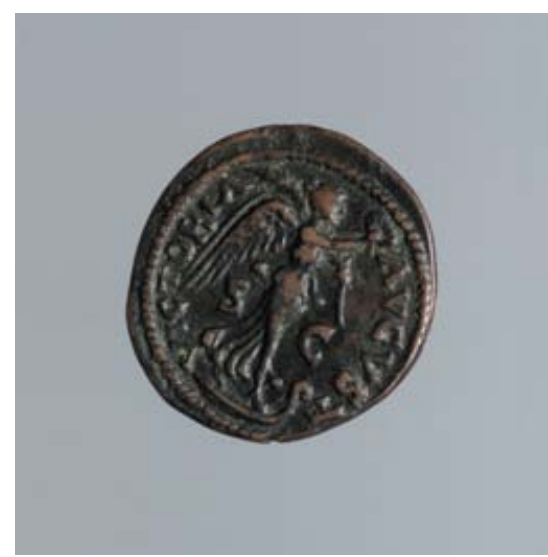

No. 37 - Rev.

Early Medieval Europe 2008 I6 (3) (C) 2008 The Authors. Journal Compilation (C) 2008 Blackwell Publishing Ltd 


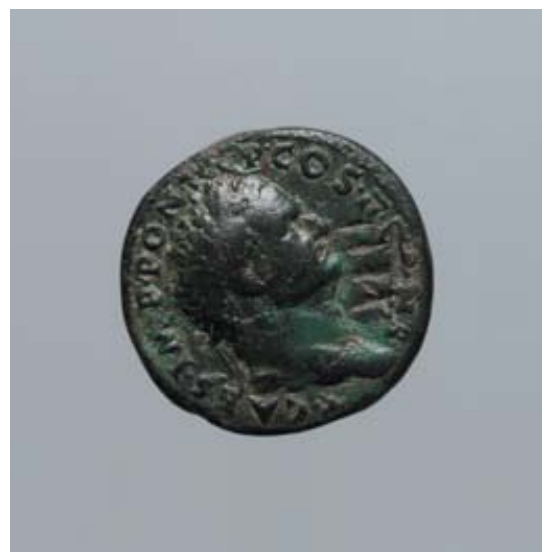

No. 38 - Obv.

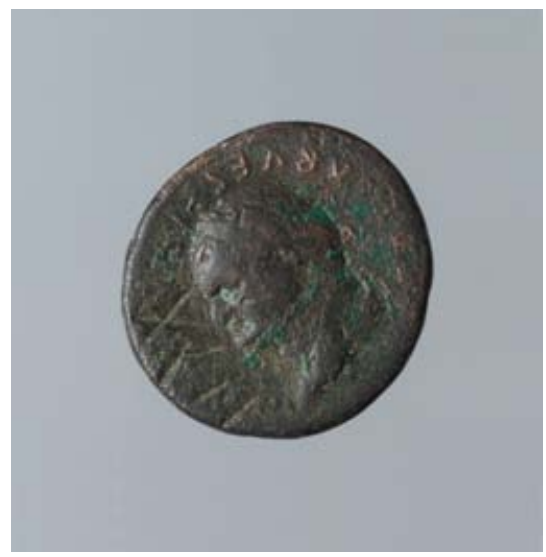

No. 39 - Obv.

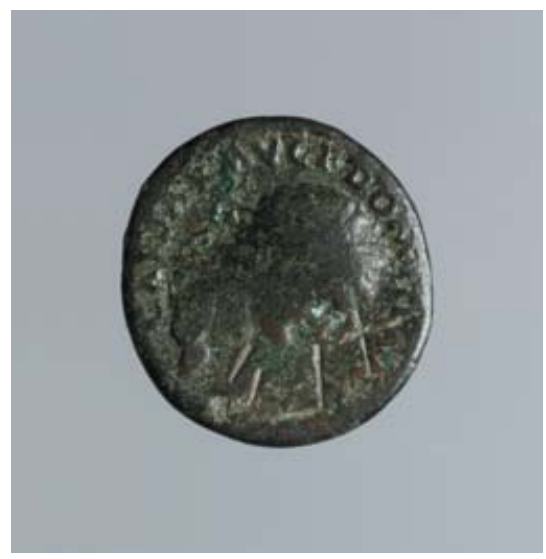

No. 40 - Obv.

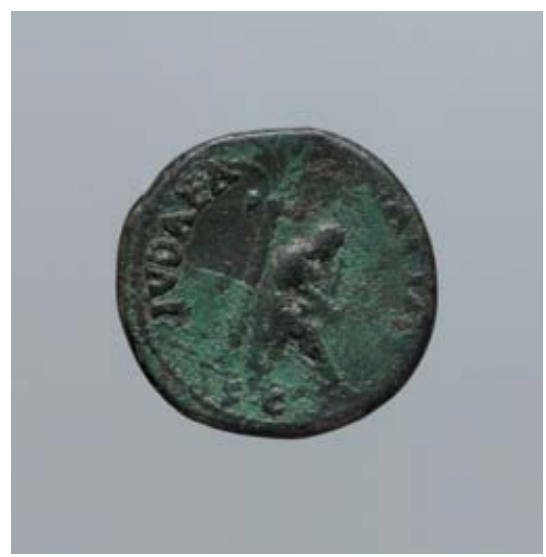

No. 38 - Rev.

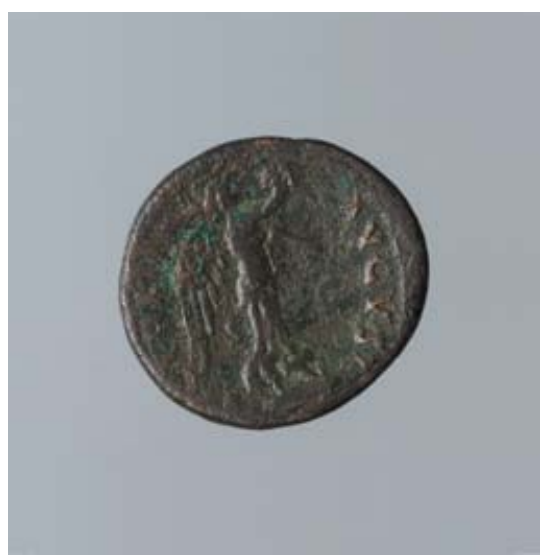

No. 39 - Rev.

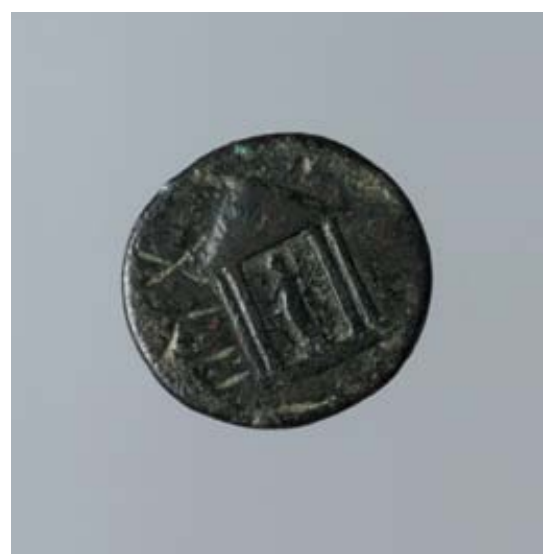

No. 40 - Rev.

Early Medieval Europe 2008 I6 (3)

(C) 2008 The Authors. Journal Compilation () 2008 Blackwell Publishing Ltd 


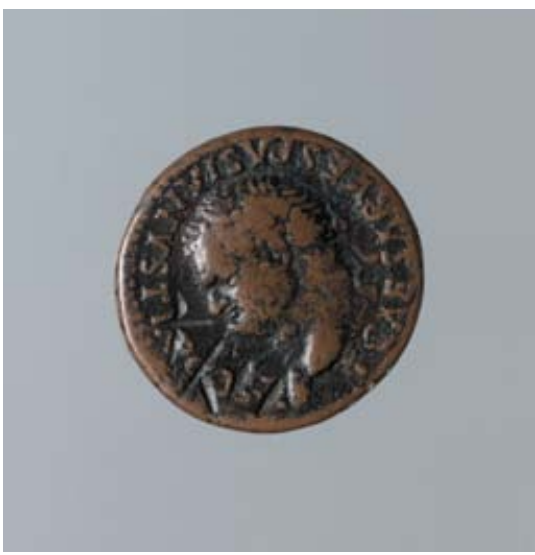

No. $41-$ Obv.

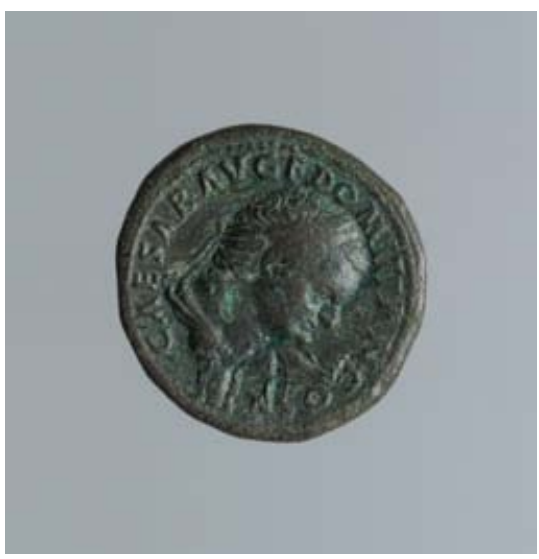

No. 42 - Obv.

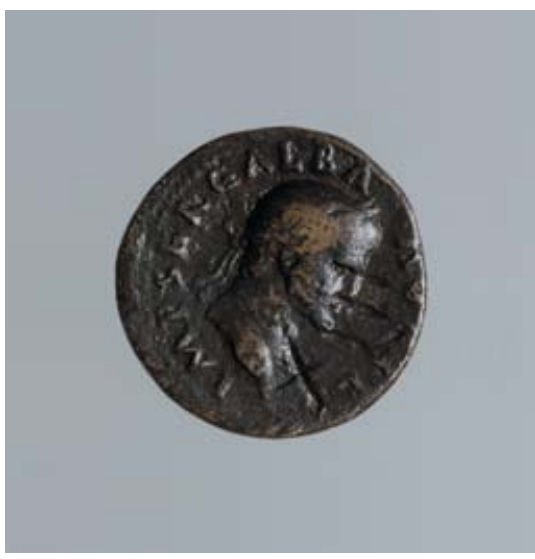

No. 43 - Obv.

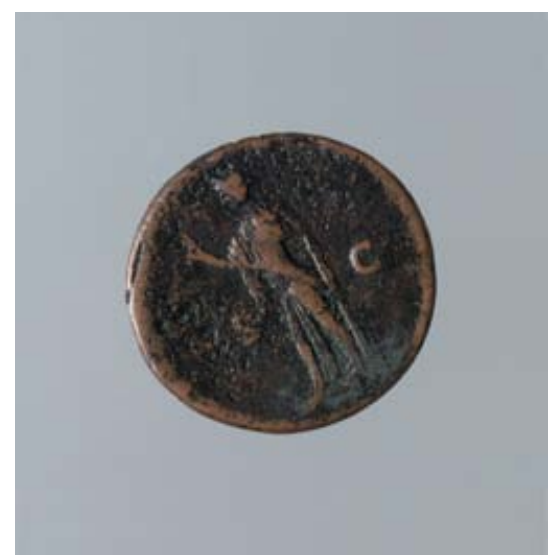

No. 41 - Rev.

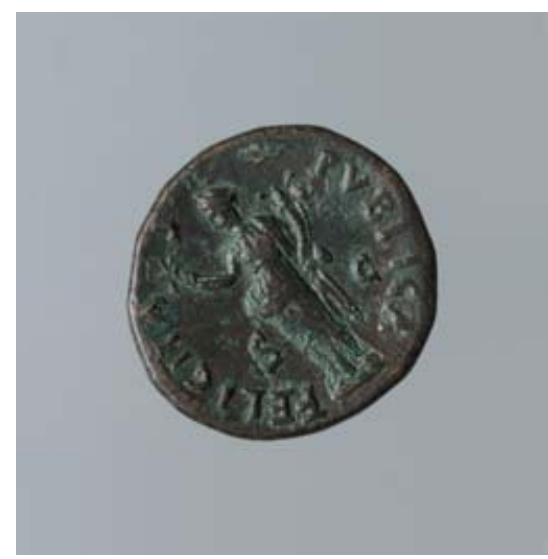

No. 42 - Rev.

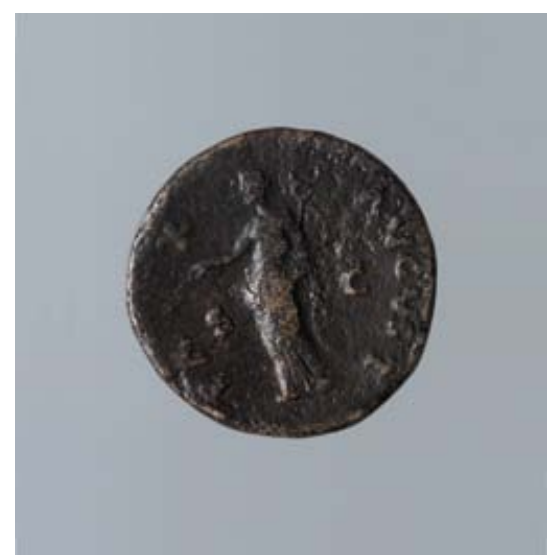

No. 43 - Rev.

Early Medieval Europe 2008 I6 (3) (C) 2008 The Authors. Journal Compilation (C) 2008 Blackwell Publishing Ltd 


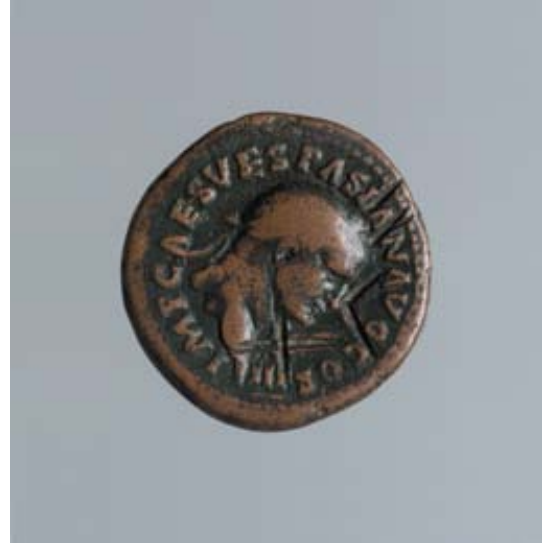

No. 44 - Obv.

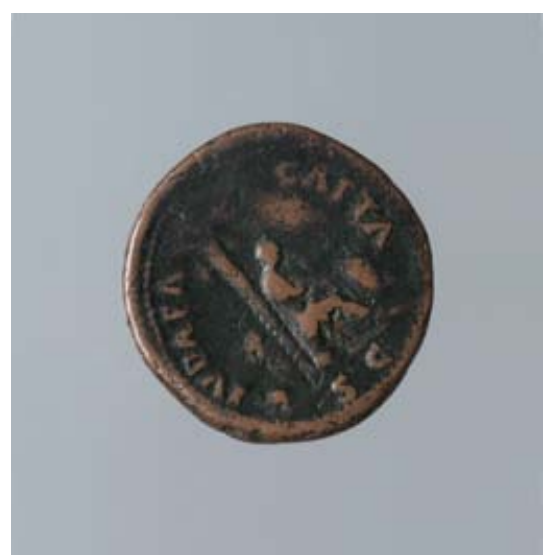

No. 44 - Rev. 